\title{
A UNIVERSALIZAÇÃO DOS DIREITOS HUMANOS SOCIAIS: A GRAMÁTICA PARA UMA COMUNIDADE MUNDIAL DE VALORES
}

\section{Fernanda Giardini Pogorelsky ${ }^{1}$}

\section{INTRODUÇÃO}

A luta do capital para dominar a capacidade criativa do trabalho vivo ${ }^{2}$ é marca registrada do capitalismo contemporâneo. Impregnado pela lógica da globalização econômica, o mundo vê-se hoje coordenado pelas leis do mercado financeiro que disseminam comportamentos competitivos perversos e aviltam a força de traba- lho. O processo globalizante é percebido como o único caminho histórico viável ${ }^{3}$, e a demanda por mecanismos que extraiam do trabalhador o máximo de resultados em nome do lucro incessante incrementa-se à custa de direitos sociais.

É inegável a expansão mundial desse fenômeno, como igualmente inconteste a propagação da miséria e da pobreza. Em todas as partes do

1 Mestre em Direito pela UNISINOS; especialista em Direito do Trabalho e Direito Processual do Trabalho pela PUCRS; professora do curso de Direito das Faculdades Integradas São Judas Tadeu - Porto Alegre.

2 ALVES, Giovanni; WOLFF, Simone. Capitalismo global e o advento de empresasrede: contradições do capital na quarta idade da máquina. Caderno $C R H$, Salvador, v. 20, n. 51, p. 515-528, set./dez. 2007, p. 518.

3 SANTOS, Milton. Por uma outra globalização: do pensamento único à consciência universal. 10 ed. Rio de Janeiro: Record, 2003, p. 36. 
globo, tal proposta recebeu ferrenhos adeptos, cegos pela reprodução da riqueza em poder dos mesmos. A internacionalização do atual modelo de desenvolvimento impõe a quebra dos limites territoriais, mas perpetua, ao mesmo tempo, a segregação de indivíduos das vantagens econômicas e do alcance dos instrumentos protetivos, transformando-os em um "exército de supérfluos"4.

Por outro lado, impulsionados pela Declaração Universal da ONU de 1948, nascem paulatinamente instrumentos internacionais voltados à proteção e universalização dos Direitos Humanos, que procuram instaurar uma nova ordem mundial, a partir da superação das limitações impostas pelas fronteiras nacionais, diga-se, pelo Estado-Nação, com "a identificação de valores comuns às diversas sociedades e grupos de uma mesma sociedade, procurando dotá-las de uma dimensão moral e jurídica de caráter universal”`. A concepção de Direitos Humanos, cujo nascimento e desenvolvimento estão intimamente associados à ordem internacional do pós-guerra e à ONU (Organizações das Nações Unidas), representa a tentativa de construção histórica de bases mínimas de convivência entre os povos universalmente aceitas: possíveis denominadores comuns, com base em uma semântica universal, ou universalista, que permita a fundação de uma comunidade mundial de valores sem exterior, cujo âmago seja a simples condição humana, superando a pretensão regulatória estatal.

Logo, os Direitos Humanos, núcleo imprescindível à vida humana em dignidade, como possível resposta ao reconhecimento da proteção e do respeito a deveres mínimos comuns mundiais, viabilizam a construção de um horizonte de sentido, gradativamente dispersando as motivações capitalistas pelo lucro e sob a regência das leis do mercado que impõem a degradação humana. Considerando que durante muito tempo os direitos econômicos sempre prevaleceram, o que diretamente acarretou total assimetria e irregularidade dos parâmetros sociais mínimos nas diversas nações, a clara desordem normativa dos Direitos Humanos é um desafio cuja

4 PIOVESAN, Flávia. Palestra IEDC - Instituto de Estudos de Direito e Cidadania. Anais eletrônicos. Disponível em: <http://www.iedc.org.br/artigo/dialogando/piovesan. htm>. Acesso em: 11 jun. 2009.

5 BARRETO, Vicente de Paulo. Direito cosmopolítico e direitos humanos. Estudos Jurídicos, São Leopoldo, v. 40, n. 2, p. 100-103, julho-dezembro 2007, p. 102. 
transposição, para construção de um sentido universal fundado em valores comuns, é indispensável ao processo de formação de uma comunidade mundial inter-humana, garantindo a identidade multicultural dos povos e norteando a tarefa de identificação e ordenação de valores comuns "pela crença no potencial das diferentes pessoas em diferentes culturas para compartilhar muitos valores e concordar em alguns comprometimentos comuns"6.

Nesse contexto, é preciso investigar a importância dos Direitos Humanos Sociais como um espaço de diálogo para redução das assimetrias culturais e, então, estabelecer os marcos fundacionais de uma comunidade mundial de valores, que proponha a conciliação entre a globalização econômica e a universalização dos Direitos Humanos como rastro para o projeto de um novo modelo de desenvolvimento econômico.

O diálogo intercultural torna-se ponto de partida para uma alternativa realista ao modelo de desenvolvimento econômico dominante. Partir das diferenças, para indicação de um padrão mínimo ético de direitos sociais universais a serem mundialmente respeitados, sob pena de atingirmos a coisificação do homem pelo homem, também permite perquirir acerca de limites à exploração humana e de direitos mínimos a serem observados por todas as nações, sobrepondo-se as diferenças culturais, para inspirar, por fim, um novo alinhamento à hegemonia globalizante.

\section{A UNIVERSALIZAÇÃO DOS DIREITOS HUMANOS: A INSERÇÃO DOS DIREITOS SOCIAIS}

Os direitos sociais são Direitos Humanos. Afirmação substanciosa, especialmente em tempos atuais, quando o mundo experimenta - e já por sucessivos séculos - uma intensa dispersão de paradigmas econômicos globalizados que pouco, ou quase nada, levam em conta tais direitos.

Com efeito, verifica-se, igualmente, que o processo de integração internacional das nações não pode propriamente ser considerado uma novidade histórica. Inicialmente com a expansão do Império Romano, mas fundamentalmente desde os meados do século $\mathrm{XV}$, por meio do expansionismo mercantilista das grandes navegações, sempre se buscou uma "cooperação"

6 SEN, Armatya Kumar. Desenvolvimento como liberdade. São Paulo: Companhia das letras, 2000, p. 279. 
política-econômica-cultural entre os povos, seja por meio do comércio, seja pela submissão das comunidades conquistadas aos conquistadores ${ }^{7}$.

O fato é que, ao longo do tempo, se verificou claramente a crescente interdependência entre os Estados, sobretudo no âmbito econômico, o que acompanhou os ideais industriais-imperialistas dos séculos XVIII e XIX, culminando, hoje, numa unipolaridade hegemônica e numa intensa aceleração do intercâmbio de bens e de pessoas, evidentes novidades históricas. Daí que, quando se fala em globalização ${ }^{8}$, deve-se, inicialmente,

7 “Globalização é o processo pelo qual o espaço mundial adquiriu unidade. O ponto de partida desse movimento remonta às Grandes Navegações europeias dos séculos XV e XVI, que conferiram unidade à aventura histórica dos povos e configuraram, na consciência dos homens, pela primeira vez, a imagem geográfica do planeta". MAGNOLI, Demétrio. Globalização: estado nacional e espaço mundial. São Paulo: Moderna, 1997, p. 7. "Globalização também não é um fenômeno novo. Ele já estava presente, por exemplo, nos antigos impérios, provocando sucessivos surtos de modernização econômica, cultural e jurídica. Na era moderna, foi impulsionado pela interação entre a expansão da cartografia, o crescente domínio das técnicas de navegação pelos ibéricos e a própria evolução do conhecimento científico. Esses foram os fatores responsáveis pelas grandes descobertas e pelos projetos ultramarinos de Portugal e Espanha, a partir do final do século XV; pelas novas formas manufatureiras desenvolvidas em Florença, Gênova, Milão, Veneza e outras cidades do norte da Itália, no século XVI; e pela formação de um sistema internacional de pagamentos baseado em letras de câmbio entre banqueiros e negociantes, tornando possível o estabelecimento de rotas globais de comércio, a exploração sistemática do ouro e da prata nas Américas, o início de um amplo e complexo processo de colonização e expansão territorial, a chegada da civilização europeia aos extremos da Ásia e a formação de estruturas decisórias dotadas de uma capacidade organizacional para controlar o meio social e político em que se realiza a acumulação de capital em escala mundial”. FARIA, José Eduardo. O Direito na economia globalizada. São Paulo: Malheiros Editores, 1999, p. 60.

8 Globalização pode ser entendida também como internacionalização, contudo, mais intensa, com clara pretensão universalizante e padronizante de condutas e pensamentos e com nítido propósito de determinação de uma homogeneidade global em diferentes esferas, econômica, política, social e cultural. Entretanto, para fins específicos de desenvolvimento do presente trabalho, o termo "globalização" foi empregado e deve ser entendido como o processo econômico expansionista do modelo socioeconômico capitalista de ideologia neoliberal como pensamento hegemônico mundial, com finalidade precípua de padronização econômica a partir do resgate de alguns antigos valores liberais de mercado do século XVIII, da mínima intervenção estatal na economia, da privatização de empresas estatais, do ingresso de transnacionais, da desburocratização do Estado e do controle de preços segundo as leis de mercado e da livre concorrência entre empresas privadas. 
localizar o interlocutor e sua perspectiva sobre o tema, de modo a precisar de qual momento e de que tipo de globalização se fala, superando a polissemia do termo .

A partir dessa "união" involuntária, mantida fundamentalmente como resultado das tensões econômicas, difundem-se pelo mundo acordos e convenções internacionais em matéria financeira, marcadamente no último quarto do século passado, período em que a globalização ingressa em sua fase mais atual, com o domínio do capitalismo como formação social, difundido em praticamente todas as partes do globo e coordenado por uma ideologia de organização da produção econômica muito própria, que pressupõe, sobretudo, a "flexibilidade" da força de trabalho. Os riscos são disseminados e o neoliberalismo firma-se como pensamento econômico hegemônico, com o resgate de valores liberais, próprios do capitalismo concorrencial do século $\mathrm{XVIII}^{10}$, com ideais de livre concorrência e ausência de entraves ao comércio e à produção, para incremento da riqueza, num evidente "fundamentalismo do livre mercado"11.

Também fruto do capitalismo, mas essencialmente obra da ideologia neoliberal imperante, o nítido desengajamento e enfraquecimento dos laços que unem capital e trabalho ${ }^{12}$ foi a causa imediata da desagregação social entre os homens. O capital globaliza-se, não respeita territórios, é privado de pátria e comanda sem ser visto; o ser humano, ao contrário, não

9 Aliás, não é demais registrar a diferenciação pretendida entre os "arquétipos” globalização e universalização. Enquanto a primeira adjetiva o processo econômico expansionista, a segunda tem uma conotação semântica de vocação universal. A primeira refere-se à expansão econômica mundial, enquanto a segunda volta-se para o papel dos Direitos Humanos.

10 É no século XVIII que o capitalismo consolida-se como formação social dominante, de modo que esse período também pode ser qualificado como capitalismo industrial já que fruto da primeira Revolução Industrial. Para os fins deste artigo, todavia, vale-se das lições de Paul Singer, que propõe quatro fases distintas, mas não estanques, ao desenvolvimento do capitalismo: concorrencial, monopolista, dirigido e neoliberalismo. SINGER, Paul. Uma utopia militante: repensando o socialismo. Petrópolis: Vozes, 1998, p. 137-182.

11 HOBSBAWM, Eric. O novo século: entrevista a Antonio Polito. São Paulo: Companhia das Letras, 2000. p. 78. Ou também "totalitarismo do mercado", nas palavras de Mireille Delmas-Marty. Três desafios para um direito mundial. Tradução Fauzi Hassan Choukr. Rio de Janeiro: Lumen Juris, 2003, p. 79.

12 BAUMAN, Zygmunt. Modernidade líquida. Tradução Plínio Dentzein. Rio de Janeiro: Jorge Zahar, 2001, p. 171. 
goza dessa mobilidade, vincula-se a determinada nação, embora assuma, em qualquer lugar que seja, condições de comportamento uniformizadas: come a mesma comida, veste as mesmas roupas, assiste aos mesmos filmes, compra os mesmos produtos, enfim, perpetua a lógica da globalização, ainda que inconscientemente.

Nessa "invariabilidade comportamental”, o capital leva larga vantagem, e, nesse processo "globalizante”, uniformiza quase tudo. Cria padrões nas mais diferentes áreas, política, econômica, social, cultural e, sobretudo, no aspecto da internacionalização da economia mundial ${ }^{13}$, permite uma série de atrocidades, alimentando a contradição do capitalismo contemporâneo na dialética exclusão versus inclusão: o crescimento do desemprego estrutural pela incapacidade progressiva de geração de empregos formais em quantidade ou qualidade adequadas (exclusão) e a queda do preço dos produtos globais pela incorporação contínua de mercados (inclusão) que ficavam à margem do consumo por falta de renda ${ }^{14}$.

A realidade cruel foi a de que o Direito - o fenômeno jurídico de gênese estatal - serviu, e ainda serve, à globalização econômica, adaptando-se às necessidades da Lex Mercatoria (lei do mercado) ${ }^{15}$, tendo permitido a degradação das relações humanas, sobretudo do ponto vista social, ao estimular o individualismo e a autonomia, com base na escolha de valores comerciais. Numa enxuta digressão

13 "Economia mundial, conceito que tem um sentido preciso: significa não apenas que os diferentes países intercambiam produtos, serviços e capitais, mas que o conjunto da superfície terrestre, excetuadas muito poucas regiões, tornou-se uma plataforma da acumulação e reprodução capitalista, não apenas em seu sentido financeiro, mas também naquilo que concerne ao capital produtivo”. COSTA, Sérgio. Democracia cosmopolita: déficits conceituais e equívocos políticos. Revista brasileira de Ciências Sociais, São Paulo, v. 18, n. 53, 2003. Disponível em: <http://www.scielo.br/scielo. php?script=sci_arttext\&pid=S0102-69092003000300002\&lng=en\&nrm=iso $>$. Acesso em: 30 jun. 2009.

14DUPAS, Gilberto. Impactos sociais e econômicos das novas tecnologias deinformação. In: SIMPÓSIO INTERNACIONAL UNIVERSIDADE E SOCIEDADE, 1999, Anais eletrônicos. São Paulo: Faculdade de Economia, Administração e Contabilidade - USP, 1999. Disponível em: <http://www.ime.usp.br/ cesar/simposio99/Dupas.htm>. Acesso em: 29 jun. 2009.

15 Cabe aqui registrar as lições de José Eduardo Faria quando afirma que um dos efeitos do fenômeno da globalização econômica foi a substituição da política pelo mercado como instância máxima de regulação social, formando "direitos autônomos, com normas, procedimentos, recursos e regras hermenêuticas próprias, entreabrindo 
histórica, verifica-se que a limitação da própria noção de comunidade mundial como inter-humana, de natureza espontânea e sedimentada na simples condição de "ser humano", está diretamente ligada ao surgimento do Direito estatal. Passa-se, gradativamente, de uma relação humana (entre homens) em escala mundial para uma relação entre Estados - interestatal -, verdadeiros intermediários, o que promoveu, diretamente, a interseção entre as comunidades humanas.

Certamente porque os Estados passaram a condutores da vida social, pouco a pouco se atesta a transposição do parentesco entre os homens à singularidade estatal, com a gradual perda dos ideais uníssonos de comunidade humana, pela assunção da lógica relativista: a sobreposição de normas jurídicas diferenciadas na origem e no conteúdo. O resultado foi um plura- lismo normativo de justaposição, na medida em que cada ordem nacional procede à sua própria positivação, sendo constante geradora e multiplicadora de normas, numa consequente infinita desordem normativa, fruto do fenômeno de globalização econômi$\mathrm{Ca}^{16}$, nascida na tentativa infrutífera de "ordenar" o mercado.

Na falta de uma base comum de integração, já na primeira metade do Século XX, a rivalidade entre as nações acirra-se e, simplificadamente, o resultado são duas grandes guerras mundiais, motivadas por claras divergências culturais, fundadas em leituras divergentes da realidade, mas ausentes de uma base comum de integração. Como mecanismo de possível pacificação, fundados na simples circunstância de "ser humano", emergem os Direitos Humanos, com o reconhecimento expresso de valores supremos

a coexistência de diferentes normatividades”. Em âmbito econômico, por exemplo, cita o autor, de um lado, a Lex Mercatoria como "o corpo autônomo de práticas, regras e princípios espontaneamente constituídos pela comunidade empresarial para autodisciplinar suas atividades"; e, de outro, o Direito de produção como "o conjunto de normas técnicas formuladas para atender às exigências de padrões mínimos de qualidade, durabilidade e segurança dos bens e serviços em circulação no mercado transnacionalizado, de especificação de seus componentes, da origem de suas matériasprimas etc”. FARIA, José Eduardo. Globalização e Justiça. In: CAMPUZANO, Afonso de Julios; OLIVEIRA JUNIOR, José Alcebíades de (Org.). O poder das metáforas: homenagem aos 35 anos de docência de Luis Alberto Warat. Porto Alegre: Livraria do Advogado, 1998.

16 DELMAS-MARTY, Mireille. Ordem jurídica mundial e paz positiva. Entrevista a Le Monde Diplomatique. Disponível em: <http://diplo.uol.com.br/2003-07,a691>. Acesso em: 29 jun. 2009. 
da igualdade, liberdade e fraternidade entre os homens ${ }^{17}$. Difundem-se, ainda que tardiamente, nas diferentes culturas que, embora variantes, acarretando a variabilidade da materialidade de tais direitos, passam a compreendê-los não como uma virtude social de determinada comunidade ou cultura específica, mas como um sistema de raciocínio ético e uma base de reivindicação política $^{18}$.

Os Direitos Humanos, com efeito, identificarão um valor comum a todos os seres humanos, que independe do local (frise-se: Estado) em que vivem ou da quantidade de bens que detêm, mas decorre de sua própria essência. A Declaração Universal dos Direitos Humanos da ONU (1948) ${ }^{19}$ instaurou o processo de internacionalização desses direitos, além de seu expresso reconhecimento jurídico ${ }^{20}$, vinculando os Estados aderentes à sua implementação. Contudo, embora sedimentados sob um valor fundante, mantêm os Direitos Humanos o dever de "tutelar apenas as diferenças que não sufocam sua missão de garantir a todos os homens enquanto tais, e não como integrantes dessa ou daquela cultura,

17 COMPARATO, Fábio Konder. A Afirmação Histórica dos Direitos Humanos. 3. ed. São Paulo: Saraiva, 2003, p. 223.

18 SEN, Armatya Kumar. Desenvolvimento como liberdade. São Paulo: Companhia das Letras, 2000, p. 264. Os direitos humanos são um espaço para onde convergem diversos pontos de vista, mas ainda um espaço de diálogo entre as diversas culturas, sobre valores comuns.

19 Deve-se reconhecer a evolução histórica dos Direitos Humanos como uma caminhada que "procura resgatar a memória da tradição que ensina e mostra determinadas atitudes como inaceitáveis, posto que atentam contra princípios humanos mais essenciais". Partindo, especificamente, dos escritos envolvendo tais direitos, documentos próprios da formação do Estado Civil, um dos primeiros instrumentos de reconhecimento expresso de determinadas prerrogativas inatas a toda e qualquer pessoa foi a Declaração de independência dos Estados Unidos da América de 1776, seguida da Declaração de Direitos do Homem e do Cidadão de 1789. Posteriormente, já no século XX, como resposta às atrocidades das Grandes Guerras, vem a Carta das Nações Unidas de 1945 e, finalmente, a Declaração Universal dos Direitos Humanos de 1948, peça-chave do processo de construção axiológica de um "conjunto de condições humanamente necessárias”. Para maiores esclarecimentos acerca das fases do processo histórico e conhecimento do resgate dos fundamentos jusnaturalistas dos direitos humanos: ENGELMANN, Wilson. A origem jusnaturalista dos direitos humanos: o horizonte histórico da declaração universal dos direitos humanos de 1948. Artigo apresentado no CONPEDI - Conselho Nacional de Pesquisa e Pós-Graduação em Direito, julho, 2009.

20 LAFER, Celso. Paz, direitos humanos e multiculturalismo. Jornal da Ciência, 20 dez. 2004. Disponível em: <http://www.jornaldaciencia.org.br/Detalhe.jsp?id=24172>. Acesso em: 30 jun. 2009. 
os direitos necessários ao exercício de sua liberdade e autonomia"21. Definitivamente porque uma pista é compreender que "as diferenças podem, em suas diversidades, estabelecerem-se em patamares de reciprocidade”22.

Em razão de abrangerem diversos valores, todos tidos como universais, indivisíveis, inter-relacionados ${ }^{23}$, para os Direitos Humanos será a cultura a fixadora de um horizonte de sentido. Por outro lado, e justamente por isso, nenhum desses direitos se afasta de seu cerne gerador - o valor da dignidade ${ }^{24}$ - pelo qual amparam sua justificativa e pelo qual se internacionalizam numa concepção mundial, estabelecendo os pontos de igualdade mínima, compartilhados por todas as culturas. Nesse aspecto, o surto glo-

122 LUCAS, Douglas Cesar. Direitos humanos e interculturalidade: um diálogo entre igualdade e diferença. Tese (Doutorado em Direito) - Programa de Pós-Graduação em Direito, Unisinos, São Leopoldo, 2008, p. 192.

22 VENTURA, Deisy de Freitas Lima; KILCA, Marcelo. Constitucionalização da União Europeia em processo: para além do meramente jurídico. Revista dos Alunos do Programa de Pós-Graduação em Integração Latino-Americana - UFSM, Santa Maria, v. 2, n. 2, 2006, p. 42.

23 LAFER, Celso. op. cit., p. 1.

24 Atribui-se classicamente a Immanuel Kant (Fundamentação da metafísica dos costumes. Tradução de Lourival de Queiroz Henkel. São Paulo: Ediouro, 1967. p. 85) a ilustre dicotomia entre preço e dignidade. Argumenta Kant que "no reino dos fins tudo possui um preço ou uma dignidade. Aquilo que tem um preço pode ser substituído por algo equivalente; por outro lado, o que se acha acima de todo preço e, portanto, não admite nada equivalente, encerra uma dignidade. $\mathrm{O}$ que se refere às inclinações e necessidades do homem tem um preço comercial; o que, sem supor uma necessidade, se conforma a certo gosto, digamos, a uma satisfação produzida pelo simples jogo, sem fim algum, de nossas faculdades, tem um preço de afeto; mas o que constitui a condição para algo que seja fim em si mesmo, isso não tem meramente valor relativo ou preço, mas um valor interno, isto é, dignidade”. Seguindo o raciocínio, tem-se que o homem, por sua vez, está acima de qualquer preço, não é passível de ser substituído por um equivalente e não pode ser usado como meio. Isso porque, a rigor, todo ser humano é uma realidade moral, ou seja, nas palavras de Roque Junges, "tem dignidade porque é fundamentalmente capaz de autorrealização” (A concepção kantiana de dignidade humana. Estudos Jurídicos, v. 40, n. 2, p. 84-87, julho-dezembro 2007, p. 86). Assim, na concepção kantiana, cada pessoa será capaz de construir de forma autônoma sua própria moralidade, a partir de valores que justifiquem e motivem suas ações, tornandoas preferíveis em detrimento de outras. Importa, para o significado da vida humana, ser bom, entendido como a capacidade de realizar sua moralidade sem perder de vista a necessária reciprocidade, ou seja, o respeito à dignidade de toda a humanidade, de todos os demais seres humanos. Considerando essencialmente que tudo que não tem 
balizante - ou melhor, universalizante - serve de apoio, como meio de instauração de uma "comunidade ${ }^{25}$ sem exterior”, que alce a proteção dos Direitos Humanos a valor transnacional.

Diversamente do momento histórico no qual emergiram, quando os Estados, pela insuficiência dos mecanismos jurídicos nacionais, viram-se incapazes de conferir proteção aos seus cidadãos diante das atroci- dades que ocorreram, na atualidade os Direitos Humanos assumem um comprometimento diferenciado. A desigualdade social e econômica crescente torna-se hoje um dos temas mais prementes dos Direitos Humanos, e a situação de disparidade entre os que têm e os que não têm acesso a condições básicas aciona com toda a força a exclusão moral ${ }^{26}$, manifesta em duas características distintas: na

preço é digno de respeito incondicional, a dignidade é o valor fundante do homem. E a igualdade na atribuição de dignidade equipara a todos eles, de forma que a pessoa humana assume a condição de fonte geradora dos demais valores. Próprio de sua época (finais do século XVIII), o pensamento de Kant ainda mantém certa atualidade e ajudou a influenciar ordenamentos jurídicos contemporâneos, alguns dos quais alçaram a categoria da dignidade da pessoa humana a princípio constitucional fundamental, como é o caso da Constituição brasileira. Contudo, a filosofia kantiana não escapa a uma releitura, sobretudo em época de globalização neoliberal, em que os paradigmas estatais tradicionais se relativizam e a suposta igualdade fundamental de todo e qualquer homem passa a contribuir para sua autodestruição: a dignidade aniquila a dignidade, mas a de outrem.

25 Conveniente, aqui, traçar a distinção entre os conceitos de comunidade e sociedade. Valem-se das lições de Mireille Delmas-Marty, em aula ministrada em 7 de setembro de 2008, em Paris, a qual, por sua vez, toma emprestada a diferença proposta por RenéJean Dupuy no sentido de que comunidade é "produto natural de uma solidariedade espontaneamente sentida”, enquanto sociedade é "fruto da vontade exigindo uma prática consciente e normas jurídicas para garanti-la”. Feito isso, registre-se que, nesse momento específico, a intenção foi tratar de comunidade, por meio de ideais comuns que unam os indivíduos numa mesma vontade: o respeito incondicional à dignidade humana. DELMAS-MARTY, Meirelle. Le rôle du droit dans l'émergence d'une communaute mondiale de valeurs. Aula ministrada, em 7 de setembro 2008, em Paris. Disponível em: <http://www.asmp.fr/travaux/communications/2008/delmas.htm>. Acesso em: 31 mai. 2009. “Une telle idée brouille em tout cas la différence évoquée par notre regretté confrère René-Jean Dupuy entre la communauté (produit naturel d'une solidarité de base spontanément ressentie) et la société (fruit de la volonté exigeant une mise em oeuvre consciente et des normes juridiques pour la garantir)”.

26 VIEIRA, Oscar Vilhena; DUPREE, A. Scott. Reflexões acerca da sociedade civil e dos direitos humanos. SUR - Revista Internacional de Direitos Humanos, ano 1, n. 1, $1^{\circ}$ semestre, 2004, p. 55. 
invisibilidade dos excluídos (pessoas que, com pouca voz e poucos meios diretos para mobilizar e constranger os que se encontram no topo, não partilham seu verdadeiro estado de dor e sofrimento aos incluídos) e na sua demonização (os excluídos são uma ameaça aos interesses dos elementos mais prósperos e mais bem colocados $)^{27}$. O econômico domina o social e cria uma clara cisão entre aqueles que dele participam e aqueles que dele são meros objetos.
Não paira qualquer dúvida, igualmente, de que estopim do processo de integração entre as nações foi a motivação econômica. Entretanto a busca pela formação de uma comunidade, que revela como necessário a presença de "um projeto único coletivo que aglutina e dá sentido à existência humana”28, há muito perdida durante a modernidade ${ }^{29}$, mas resgatada após duas grandes guerras mundiais, em que a cooperação entre os povos tornou-se cada vez mais imprescin-

27 VIEIRA, loc. cit.

28 GALUPPO, Marcelo Campos. A epistemologia jurídica entre o positivismo e o póspositivismo. Revista do instituto de hermenêutica jurídica, Porto Alegre, vol. 1, n. 3, 2005, p. 195.

29 “'...] o qualitativo 'moderno' designa os desenvolvimentos intelectuais e institucionais da filosofia jurídica e política que se estendem do fim da Segunda Escolástica até o século XIX. Neste sentido é conveniente estabelecer bem a distinção entre 'moderno' e 'contemporâneo', mesmo que a época contemporânea esteja profundamente marcada com a forma dessa 'modernidade' e não esteja resolutamente engajada em uma vida pós-moderna”. ARNAUD, André-Jean. $O$ direito entre a modernidade e a globalização: lições de filosofia do direito e do Estado. Tradução de Patrice Charles Wuillaume. Rio de Janeiro: Renovar, 1999, p. XVI, nota de rodapé $n^{\circ} 1$. É no alvorecer da modernidade, com a formação dos Estados-Nação na Europa continental e com a vitória do racionalismo, que assume o direito uma concepção mecanicista, lógica, de verdades absolutas, desapegado da ética dos valores. Extremamente individualista, determinado por uma verdade incontestável, baseado em um método científico (inspirado por Descartes), o direito é estruturado numa perspectiva lógica-dedutivadogmática, completamente separado da moral, sendo privado de seu fundamento axiológico originário e objetificado enquanto normatividade dogmática estatal. Dá-se a vitória da parte - o sujeito - em detrimento do todo - a coletividade. A normatividade, com a pretensão de universalidade e abstração, não mais decorre de algo apriorístico, mas brota da subjetividade humana, como expressão do sujeito pensante. Assumindo a condição de sistema normativo, o direito passa a ser identificado como a norma jurídica e, transformado num programa político, desvincula-se de sua tradição axiológicanormativa, obra da filosofia prática, visão clássica de mundo. Na sociedade pósindustrial, regida pelo total esvaziamento axiológico, em que a ciência assume o lugar da ética, o direito, identificado com o cientificismo empírico, com um pragmatismo utilitarista, fundamentos da vida contemporânea, transforma-se num mecanismo 
dível, encontra na Europa seu exemplar mais apurado. Basta uma rápida análise, por exemplo, nos tratados da União Europeia ${ }^{30}$ que se sucederam no tempo para que rapidamente se perceba o quanto o avanço econômico superou - e ainda supera - a "tentativa” (diga-se tentativa porque há clara resistência de algumas nações ${ }^{31}$ ao diálogo) de fortalecimento da universalização dos Direitos Humanos e, principalmente, indo um pouco mais além, dos Direitos Humanos Sociais.

Por tudo isso, é chegada a hora do pulso universalizante permitir a disseminação de novas concepções, amparadas nas premissas propostas pelos Direitos Humanos, em especial na sua dimensão social. Nessa lógica, a expressão da emergência de uma mesma vontade de reconhecer direitos comuns a todos os seres humanos, importando a universalidade um compartilhar de sentidos ${ }^{32}$, igualmente inspira a preocupação com os direitos sociais, que procuram superar a visão expansionista da precarização das relações, para fundação de uma comunidade mundial inter-humana que vê a dignidade como valor fundante do qual é dotada toda a humanidade.

Restaurada como valor transnacional e protegida por mecanismos supranacionais, a dignidade iguala a

finalístico-estratégico e a legislação revela-se em expressão ideológica da corrente política dominante.

30 Inicialmente, com a Comunidade do Carvão e do Aço em 1951, pelo Tratado de Paris; depois com a Comunidade Econômica Europeia em 1957, pelo Tratado de Roma; e, mais tarde, em 1992, com o nascimento da União Europeia, por meio do Tratado de Maastricht, o continente europeu - sobretudo o oeste europeu - veio num fundamental e crescente processo de integração. "Na atualidade, a Comunidade Europeia é a única detentora de personalidade jurídica internacional e interna, e por essa razão é capaz de subscrever tratados internacionais e outros contratos, comparecer em juízo e demandar, aderir a organizações internacionais etc. Logo, a União Europea não é, ao menos no plano formal, um sujeito de direito internacional. A situação é ambígua, pois a Comunidade é, em verdade, um subconjunto da União Europeia. Via de consequência, boa parte da doutrina comunitária considera que se trata de uma falsa questão, pois embora desprovida de atribuição formal de personalidade, o mero raciocínio lógico indica a dificuldade de conceber a União sem identificá-la como sujeito de direito". VENTURA, Deisy de Freitas Lima. Critica al proyecto de Constitución Europea (“Constitución parcial”): La Convención como modesto laboratorio del constitucionalismo supranacional. Revista de Derecho Privado y Comunitario, Buenos Aires, 2003-3, p. 611-627.

31 Aliás, circunstância claríssima ao se verificar as assimetrias nas ratificações dos instrumentos internacionais.

32 DELMAS-MARTY, Mireille. Três desafios para um direito mundial. Tradução Fauzi Hassan Choukr. Rio de Janeiro: Lumen Juris, 2003, p. 19. 
condição intrínseca de todo homem e refuta sua coisificação. $\mathrm{O}$ homem então se compreende como agente moral pleno, capaz de perceber a sua igualdade e a do outro, dispondo-se a cooperar e promover a realização social de todas as dignidades ${ }^{33}$.

Por outro lado, a proposta de universalização dos direitos sociais, aqui encarados como uma "face" dos Direitos Humanos (se é que se pode cindi-los em partes, mas se assim e aqui foi feito deve-se ao respeito à historicidade dos direitos em observância à própria evolução do Estado, mas sem esquecer que, como alerta Mireille Delmas-Marty, tem-se de reconhecer a interdependência entre economia e Direitos do Homem, razão pela qual a separação dos Direitos Humanos em "civis e políticos" e "econômicos, sociais e culturais”, fruto de pactos adjacentes à Declaração Universal ${ }^{34}$, revela "uma classificação superficial sem

33 "A dignidade especial do ser humano não consiste em viver como um exemplar da sua espécie, mas a cada ser humano é dada uma tarefa específica e proporcionada: ser sob o ponto de vista moral e pela força de sua liberdade um ser humano bom. O significado da vida humana não é estar bem, mas ser bom”. JUNGES, José Roque. A concepção kantiana de dignidade humana. Estudos Jurídicos, São Leopoldo, v. 40, n. 2, p. 84-87, julho-dezembro 2007, p. 86-87.

34 Tratam-se, especificamente, dos pactos internacionais de direitos econômicos, sociais e culturais (PIDESC) e de direitos civis e políticos (PIDCP), adotados pela Assembleia Geral das Nações Unidas em 1966, como "instrumentos de adicional proteção dos Direitos Humanos, destinados a ser usados quando vierem a falhar as instituições nacionais na concretização da justiça. Na verdade, os direitos consagrados nos dois pactos deveriam constituir um só instrumento normativo, mediante a visão de indivisibilidade dos Direitos Humanos. Pressões de muitos países fizeram com que eles fossem reunidos em dois pactos, para o que alegavam, principalmente, que os direitos humanos civis e políticos eram autoaplicáveis e passíveis de cobrança imediata, enquanto que os direitos humanos econômicos, sociais e culturais eram 'programáticos'”. LIMA JÚNIOR, Jayme Benvenuto. Os direitos humanos econômicos, sociais e culturais. Rio de Janeiro: Renovar, 2001, p. 31. De sua parte, Antônio Augusto Cançado Trindade alerta que a distinção consagrada "nos dois Pactos das Nações Unidas afigurou-se, antes, como um reflexo da profunda divisão ideológica do mundo no início dos anos cinquenta, a repercutir inexoravelmente nos trabalhos das Nações Unidas. No presente domínio, por exemplo, o então 'grupo ocidental' enfatizava os direitos civis e políticos, ao passo que o então 'bloco socialista' privilegiava os direitos econômicos, sociais e culturais. Não há que passar despercebido, no entanto, que tal compartimentalização não havia sido antecipada ou propugnada pelos redatores da Declaração Universal de 1948”. Tratado de direito internacional dos direitos humanos. V. 1. Porto Alegre: Sérgio Fabris Editor, 1997, p. 355. 
qualquer verdadeira reflexão teórica sobre cada categoria”35), agrega-se à proposta de hierarquia de valores. Se os Direitos Humanos são alçados ao ápice como retrato da proteção do direito à dignidade, os direitos sociais, por sua vez, como parte desse conjunto coerente e indivisível, são valores a universalizar.

Indubitavelmente, valor pode ser compreendido como tudo aquilo que guia, motiva, direciona, intenciona, estimula as ações humanas. Os valores não são circunstâncias dadas pelo direito, mas sempre construídas e, por isso, são variáveis no tempo e no espaço, esbarrando na questão do multiculturalismo, ou seja, o que é valor para determinada comunidade cultural, pode não ser para outra. Contudo, justamente em razão desse dado, dá-se a relevância dos Direitos Humanos, percebidos como um denominador comum, uma base comum de entendimento entre as culturas que não pode ser contrariada. Não se trata aqui de uma homogeneidade cultural imposta, mas, sim, da missão conferida aos Direitos Humanos de garantir a todos os seres humanos os direitos necessários ao exercício pleno de sua humanidade.

Pensar uma pauta axiológica comum para formação de uma comunidade mundial, com a inserção de direitos sociais, é também encarar a necessidade dos Direitos Humanos nortearem, guiarem, direcionarem as condutas humanas, atribuindo-lhes a condição de um valor transnacional que encontra nas diferentes culturas sua limitação semântica, porém, invoca a atribuição de direitos à simples condição humana. Instaura-se, então, um novo momento para a atual realidade capitalista flexível. Oponíveis aos ditames econômicos, os Direitos Humanos Sociais barram a exclusão e, como fonte comum propulsora, restauram os laços que unem capital e trabalho, concebendo um viés ético às condutas comerciais e, do ponto de vista da concessão de melhores condições de subsistência aos trabalhadores, o respeito a normas sociais mínimas ${ }^{36}$ que consagram, em última análise, seu maior valor intrínseco, a dignidade, e primam pela igualdade essencial inerente a todo o ser humano.

36 DELMAS-MARTY, Mireille. Três desafios para um direito mundial. Tradução Fauzi Hassan Choukr. Rio de Janeiro: Lumen Juris, 2003, p. 42.

37 DELMAS-MARTY, Mireille. Três desafios para um direito mundial. Tradução Fauzi Hassan Choukr. Rio de Janeiro: Lumen Juris, 2003, p. 60. 


\section{A FUNDAÇÃO DE UMA COMUNIDADE MUNDIAL DE VALORES}

Mas, enfim, o que instaura a universalização desses valores? Como encontrar um denominador comum entre culturas diferentes e, até mesmo, antagônicas? O direito, por si só, é suficiente ou se deve percorrer o caminho do direito à ética?

O direito confere maior estabilidade aos princípios e diretrizes que rege ${ }^{37}$, porém é menos evolutivo: com- porta paradigmas fixos e, ainda que tenha a pretensão global, atende muito mais aos interesses das nações poderosas ocidentais, desconsiderando as peculiaridades culturais. Ademais, o direito não tem o condão de criar valores, ele não é apto a revelar as circunstâncias que orientam as condutas humanas, apenas as indica, ou ainda, as nomina. Na verdade, a função do direito seria a de garantir a identidade cultural dos povos e, portanto, o próprio multiculturalismo. Todavia, o sentimento de pertencimento a deter-

37 O direito, a norma jurídica positiva, está intimamente ligado à questão da forma, razão pela qual se torna insuficiente para instauração da universalização de valores. Por isso, mostra-se necessário, ainda que brevemente, (re)visitar a história, particularmente a era clássica do Direito Romano, em que o verdadeiro direito era o que estivesse em sintonia com a justiça, havendo a clara distinção entre jus e lex. Contudo, na atualidade, encarase a surpreendente "politização do direito", obra do positivismo jurídico. A proposta positivista, ao determinar a objetificação do direito, reduzindo-o ao sistema normativo vigente, retira-lhe qualquer autonomia, transformando-o num mero instrumento de poder, usado para qualquer fim. A produção normativa volta-se ao atendimento dos interesses dos "políticos de plantão" e a vida pública resta por ser determinada pelas normas jurídicas vigentes, elaboradas pelo poder legislativo. Mas o verdadeiro direito - se é que pode existir um falso-direito - não é um sistema lógico de normas silogísticosubsuntivo. Na medida em que transformado em mero instrumento de um programa legislativo e servindo às conveniências de determinada concepção política, o direito deixa de ser direito. Só a autonomia permite que o direito seja direito. Com a perda de sua autonomia, o direito torna-se um simples fim social, um meio para os fins teológicos da política, valendo para qualquer finalidade e a serviço de todo e qualquer objetivo. $\mathrm{Na}$ sociedade pós-industrial, regida pelo total esvaziamento axiológico, em que a ciência assume o lugar da ética, o direito, identificado com o cientificismo empírico, com um pragmatismo utilitarista, fundamentos da vida contemporânea, transforma-se num mecanismo finalístico-estratégico e a legislação revela-se em expressão ideológica da corrente política dominante. Mas o fenômeno jurídico não é política, tem relação com a ética, com a filosofia prática helenística. Da resolução dos problemas jurídicos surge o direito, como expressão de toda consciência axiológica de determinada cultura, tendo por base uma fundamentação prático-normativa para resolução dos conflitos sociais com fins de produzir uma justiça material. Vale dizer, no direito é preciso valorizar o conteúdo e depois a forma. 
minada comunidade é essencialmente voluntário, já que "o direito não torna todas as diferenças compatíveis" ${ }^{38}$ e a importância da função atribuída aos Direitos Humanos está justamente na aproximação dessas distinções como uma base comum fundante entre as culturas não compulsórias.

Por outro lado, "a ética depreende, ocasião por ocasião, soluções que são necessariamente evolutivas" ${ }^{39}$, porém repercute numa instabilidade demasiada e, consequentemente, em insegurança. A ideia de valores, contudo, importa necessariamente em uma reflexão ética, mas "para hierarquizar os valores, para responsabilizar aqueles que os transgridem, a ética não basta" ${ }^{40}$. Há a necessidade da conjugação dos dois fatores (direito e ética) no objetivo de "harmonizar-se de maneira positiva à promoção de valores, ou de modo negativo sobre as principais proibições”" ${ }^{41}$. Daí que, tratando-se de valores, "a hierarquia parece clara: em caso de conflito, os valores não mercantis, que não tem equivalente e não são substituíveis, deveriam ser superiores" ${ }^{\prime 2}$.

Dito isso, percebe-se que a instauração de valores universalizáveis ou universais depende de uma construção axiológica. Os valores devem ser construídos em harmonização com as diferentes culturas. O nascimento e desenvolvimento de direitos reconhecidos a todas as pessoas expressamente declara "a possibilidade de construir historicamente bases mínimas de convivência entre os povos que sejam universalmente aceitas”43, a partir de uma semântica universal,

38 DELMAS-MARTY, Mireille. Três desafios para um direito mundial. Tradução Fauzi Hassan Choukr. Rio de Janeiro: Lumen Juris, 2003, p. 118.

39 DELMAS-MARTY, Mireille. Aula do Collège de France de 18 de março de 2008. Áudio disponível em: <http://www.college-de-france.fr/default/EN/all/int_dro/cours_ du_25_mars_diffuse_le_1.jsp>. Acesso em: 30 jun. 2009.

40 DELMAS-MARTY, Mireille. Entrevista para Lettre du Collège de France, $\mathrm{n}^{\circ} 22$, fév. 2008. Disponível em: <http://www.college-de-france.fr/media/int_dro/UPL17566_ J22INTDELMAS.pdf>. Acesso em: 30 jun. 2009. "Pour hiérarchiser les valeurs, pour responsabiliser ceux qui les transgressent, l'éthique ne suffit pas".

41 DELMAS-MARTY, loc. cit. “Selon que l'objectif est de s'accorder de façon positive sur les valeurs à promouvoir, ou de façon négative sur les principaux interdits [...]”.

42 DELMAS-MARTY, Mireille. Ordem jurídica mundial e paz positiva. Entrevista a Le Monde Diplomatique. Disponível em: <http://diplo.uol.com.br/2003-07,a691>. Acesso em: 29 jun. 2009.

43 GONZÁLEZ, Rodrigo Stumpf. A retórica dos direitos humanos. In: SANTOS, André Leonardo Copetti; STRECK, Lenio Luiz; ROCHA, Leonel Severo. Constituição, sistemas sociais e hermenêutica: programa de pós-graduação em Direito da UNISINOS: mestrado e doutorado. Porto Alegre: Livraria do Advogado, 2007, p. 179. 
ou universalista, que permita a fundação de uma comunidade mundial de valores sem exterior, cujo âmago é a simples condição humana, superando a pretensão regulatória normativa relativista estatal.

Esse fenômeno é perfeitamente detectado quando se trata de Direitos do Homem. Ainda que fundamentais e fundadores,

os Direitos Humanos funcionam menos como conceitos fundando uma base de valor universal a determinar, por antecipação, respostas uniformes e estáveis, e mais como processos transformadores, a deflagrar um movimento de compatibilização de diferenças. Isto é, de aproximação e não necessariamente de uniformização ${ }^{44}$.

A proposta, de fato, não se confunde com uniformização. "Universalizar” relaciona-se muito mais ao objetivo de fixar denominadores comuns de sentido, que aproximam as culturas, com base em um diálogo aprofundado de questões mundiais relevantes, do que a imposição hegemônica generalizada do mais forte. Certamente os Direitos Humanos revelam-se, nesse processo, como um fator de evolução, de caráter transformador.

O estabelecimento de um mínimo comum de valores em uma sociedade intercultural mundial a partir da pauta proposta pelos Direitos $\mathrm{Hu}$ manos, para construção e ordenação de valores consensuais destinados à constituição de uma verdadeira comunidade mundial (diga-se, espontânea), é um processo evolutivo de mais de sessenta anos ${ }^{45}$. A Declaração de 1948 generalizou o impulso, com a clara e expressa menção à universalidade desses direitos. Posteriormente o processo se estende com outros pactos internacionais que se seguem, por exemplo, a Declaração da Unesco

44 DELMAS-MARTY, Mireille. Aula do Collège de France de 18 de março de 2008. Áudio disponível em: <http://www.college-de-france.fr/default/EN/all/int_dro/cours_ du_25_mars_diffuse_le_1.jsp>. Acesso em: 30 jun. 2009.

45 O estopim veio com a Carta das Nações Unidas de 26 de junho de 1945, imediatamente após o fim da Segunda Guerra. Contudo, não se pode ser completamente ingênuo. "Aux lendemains de la Seconde Guerra mondiale, le Charte de l'ONU pose cenpendant des règles à vocation universelle pour tenter de canaliser le recours à la force. Mais ces règles se limitent pour l'essentiel (avec un succès variable) à la 'paix négative', l'absence de guerre. N'ayant pour objet ni de réduire les desequilibres économiques et financiers, ni d'apaiser les conflits ethniques et religieux, la Charte ne donne pas les moyens à l'ONU de bâtir la 'paix positive'”. DELMAS-MARTY, Mireille. Les forces imaginantes du droit. Le relatif et l'universel. Paris: Éditions du Seuil, 2004, p. 23. 
de $2005^{46}$ que, por sua vez, registra a necessidade de respeito à diversidade cultural (art. $2^{\circ}$ ) e explicita que todas as culturas têm a mesma dignidade.

"Amultiplicidadedas culturasedas línguas - a Torre de Babel - exprime o pluralismo da condição humana, mas a convivência pacífica de múltiplas culturas em interação permanente exige a capacidade de traduzir de uma para outra" ${ }^{47}$. A universalização dos Direitos Humanos e a preservação das diferenças culturais, embora aparentemente conflitantes, têm em comum o alcance semântico, ou seja, os Direitos Humanos como uma linha limítrofe de sentido para as diversas manifestações de cultura, sem a necessária incompatibilidade.

Hoje nitidamente se percebe que "os dispositivos ligados às pessoas (direitos da pessoa e da humanidade sob as diversas formas), proclamados universais, permanecem, na prática, dependentes da ordem jurídica nacional”, enquanto apenas os conceitos do mercado já podem ser aplicados universalmente ${ }^{48}$. Nessa perspectiva, a comunidade mundial deve repensar os mecanismos precarizadores das relações sociais próprios do capitalismo neoliberal e disseminar a ideia de que todos os homens são iguais em dignidade, de tal sorte que nenhum ser humano possa ser tratado como mero objeto ou coisa, servindo simplesmente como meio para a reprodução da riqueza. Aliás, no instante em que se puder dar preço a qualquer pessoa que seja, dignidade inexistirá ${ }^{9}$. "Em síntese, num mundo globalizado animado pelo ideal da paz não cabe o isolacionismo moral, mas a hospitalidade universal”50.

46 ORGANIZAÇÃO DAS NAÇÕES UNIDAS PARA A EDUCAÇÃO, A CIÊNCIA E A CULTURA - UNESCO. Declaração Universal sobre Bioética e Direitos Humanos de 19 de outubro de 2005. Disponível em: <http://unesdoc.unesco.org/ images/0014/001461/146180S.pdf $>$. Acesso em: 14 dez. 2009.

47 LAFER, Celso. Paz, direitos humanos e multiculturalismo. Jornal da Ciência, 20 dez. 2004. Disponível em: <http://www.jornaldaciencia.org.br/Detalhe.jsp?id=24172>. Acesso em: 30 jun. 2009, p. 2.

48 DELMAS-MARTY, Mireille. Ordem jurídica mundial e paz positiva. Entrevista a Le Monde Diplomatique. Disponível em: <http://diplo.uol.com.br/2003-07,a691>. Acesso em: 29 jun. 2009.

49 SARLET, Ingo Wolfgang. Dignidade da Pessoa Humana e Direitos Fundamentais na Constituição de 1988. 2. ed. Porto Alegre: Livraria do Advogado, 2002, p. 52.

50 LAFER, Celso. Paz, direitos humanos e multiculturalismo. Jornal da Ciência, 20 dez. 2004. Disponível em: <http://www.jornaldaciencia.org.br/Detalhe.jsp?id=24172>. Acesso em: 30 jun. 2009, p. 2. 
Diante disso, mas sobretudo pela evidente desigualdade social e econômica mundial, na atualidade a concretização do "bem-estar das massas" deve superar a condição instrumental da economia e sobrepor-se, insculpida em uma linguagem comum. A formação de "uma tal comunidade só pode existir se o reconhecimento de valores comuns contribuir para determinar o sentido das normas aplicáveis" ${ }^{51}$. A necessidade é "desenvolver uma lógica dos direitos humanos - que podemos chamar de cosmopolitismo ético - que convença os indivíduos, os grupos e as sociedades a tratar cada indivíduo como sujeito de igual valor intrínseco" ${ }^{2}$.
A disseminação universal dos Direitos Humanos como instrumento de união espontânea entre os indivíduos (o "direito dos direitos" mesma pretensão fundada em valores comuns, faz emergir a superação da crença de "alterar o status quo pela simples mudança legislativa" 54 . O discurso se propõe ao compartilhamento de sentidos, a partir de uma linguagem moral compartilhada que estabeleça os limites mínimos respeitáveis ${ }^{55}$.

Nesse processo, os instrumentos internacionais que se sucederam no tempo revelam preponderância ao identificar pontos de contato entre os Estados signatários e patamares de solidariedade. À Declaração Univer-

51 DELMAS-MARTY, Mireille. Les forces imaginantes du droit. Le relatif et l'universel. Paris: Éditions du Seuil, 2004, p. 23. "Mais une telle communauté ne peut exister que si la reconnaissance de valeurs communes contribue à déterminer le sens dês normes applicables. Autrement dit, elle postule um universalisme des valeurs que le relativisme obstiné des faits contredit chaque jour".

52 VIEIRA, Oscar Vilhena; DUPREE, A. Scott. Reflexões acerca da sociedade civil e dos direitos humanos. SUR - Revista Internacional de Direitos Humanos, ano 1, n. 1, $1^{\circ}$ semestre, 2004, p. 57.

53 “[...], progride a ideia de reconhecer aos direitos do homem o papel de um 'direito dos direitos', marcando a expressão, ao mesmo tempo, seu lugar novo na teoria e na prática dos sistemas jurídicos e sua vocação nova, não somente de protesto mas também de harmonização dos diversos sistemas. Para além do 'ideal comum' proclamado pela Declaração Universal de 1948, ou de 'linguagem comum da Humanidade', evocada pelo secretário-geral da ONU na abertura da Conferência Mundial de Viena sobre os direitos do homem, o documento adotado no desfecho dessa conferência em junho de 1993 salienta que a Declaração Universal constitui doravante um 'modelo a ser seguido'”. DELMAS-MARTY. Por um direito comum. São Paulo: Martins Fontes, 2004, p. XI.

54 LIMA JÚNIOR, Jayme Benvenuto. Os direitos humanos econômicos, sociais e culturais. Rio de Janeiro: Renovar, 2001, p. 36.

55 Ibid., p. 57. 
sal seguiram-se o Pacto Internacional de Direitos Civis e Políticos e o Pacto Internacional de Direitos Econômicos, Sociais e Culturais, ambos de $1966^{56}$, e, mais tarde, em 1986, a Declaração sobre o Direito ao Desenvolvimento, reconhecendo que o direito ao desenvolvimento é direito humano inalienável (art. $\left.1^{\circ}\right)$. Este último, aliás, constituído "na eliminação de privações de liberdade que limitam as escolhas e as oportunidades das pessoas de exercer ponderadamente sua condição de agente" 57 , percebido como um direito de terceira geração $0^{58}$. Não é demais mencionar, igualmente, outros pactos internacionais relativamente à internacionalização dos Direitos Humanos, como, por exemplo, a Convenção Internacional sobre a Eliminação de todas as Formas de Discriminação Racial (1965), a Convenção sobre as mulheres (1979), a Convenção sobre os Direitos da criança (1989), a Convenção relativa ao Estatuto do Refugiado (1951), além de outras convenções e protocolos referentes ao Direito Internacional Humanitário, à Cooperação Internacional, à pena de morte e ao trabalho e emprego, estes últimos especificamente da OIT $^{59}$ (Organização Internacional do Trabalho).

$56 \mathrm{O}$ que evidencia a conjugação do valor liberdade com o da igualdade. "Vale dizer, sem a efetividade dos direitos econômicos, sociais e culturais, os direitos civis e políticos se reduzem a meras categorias formais, enquanto sem a realização dos direitos civis e políticos, ou seja, sem a efetividade da liberdade entendida em seu mais amplo sentido, os direitos econômicos, sociais e culturais carecem de verdadeira significação. Não há mais como cogitar da liberdade divorciada da justiça social, como também infrutífero pensar em justiça social divorciada da liberdade. Em suma, todos os direitos humanos constituem um complexo integral, único e indivisível, no qual os diferentes direitos estão necessariamente inter-relacionados (sic) e são interdependentes entre si”. PIOVESAN, Flávia. Direitos humanos e o direito constitucional internacional. 8. ed. rev., ampl. e atual. São Paulo: Saraiva, 2007, p. 141-142.

57 SEN, Armatya Kumar. Desenvolvimento como liberdade. São Paulo: Companhia das letras, 2000, p. 10.

58 LAFER, Celso. Paz, direitos humanos e multiculturalismo. Jornal da Ciência, 20 dez. 2004. Disponível em: <http://www.jornaldaciencia.org.br/Detalhe.jsp?id=24172>. Acesso em: 30 jun. 2009, p. 1.

59 A título exemplificativo, considerando os diversos instrumentos da OIT, mencionese a Convenção $n^{\circ} 111$ sobre a Discriminação em matéria de Emprego e Profissão, a Convenção $n^{\circ} 105$ sobre a Abolição do Trabalho Forçado, a Convenção $n^{\circ} 138$ sobre a Idade Mínima de Admissão ao Emprego, a Convenção n 98 sobre a Aplicação dos Princípios do Direito de Organização e de Negociação Coletiva e a Convenção ${ }^{\circ} 182$ sobre a Interdição das Piores Formas de Trabalho das Crianças e a Ação Imediata com vista à sua Eliminação. 
A Declaração de 1948 volta a ser reafirmada, em 1993, na Segunda Grande Conferência Mundial de Direitos Humanos de Viena, em que "a linguagem, a gramática contemporânea da Declaração vem enfatizada" ${ }^{60}$. Realizada após os impactos do fim da Guerra Fria e de seus conflitos ideológicos, a Conferência da ONU adensou a "asserção jurídica e diplomática da abrangência do 'direito a ter direitos'”'”1. As aspirações voltam-se a transformar os "Direitos Humanos como roteiro emancipatório" 62 , fomentando a abertura do diálogo multicultural como "condição para a celebração de uma cultura dos direitos humanos, inspirada pela observância do 'mínimo ético irredutível', alcançado por um universalismo de confluência"63.

Todavia, deve-se registrar que a internacionalização dos instrumentos relativos aos Direitos Humanos, vinculando os Estados signatários ao seu conteúdo, muito ainda "supõe a existência de relações necessárias entre as nações" ${ }^{4}$. O desafio é ultrapassar fronteiras ${ }^{65}$, é propagar um intercâmbio na busca de uma disseminação universalista e compartilhada de sentidos. O Estado-Nação mantém-se como "um ponto de referência obrigatório" 66 , contudo redefinem-se suas funções ${ }^{67}$.

60 PIOVESAN, Flávia. Palestra IEDC - Instituto de Estudos de Direito e Cidadania. Anais eletrônicos. Disponível em: <http://www.iedc.org.br/artigo/dialogando/piovesan. htm>. Acesso em: 11 jun. 2009.

61 LAFER, Celso. op. cit. p. 1.

62 SANTOS, Boaventura de Sousa. Por uma concepção multicultural de direitos humanos. In: SANTOS, Boaventura de Sousa (Org.). Reconhecer para libertar: os caminhos do cosmopolitismo multicultural. Rio de Janeiro: Civilização Brasileira, 2003, p. 438.

63 PIOVESAN, Flávia. Direitos humanos e o direito constitucional internacional. 8. ed. rev., ampl. e atual. São Paulo: Saraiva, 2007. p. 155.

64 ARNAUD, André-Jean. O direito entre a modernidade e a globalização: lições de filosofia do direito e do Estado. Tradução de Patrice Charles Wuillaume. Rio de Janeiro: Renovar, 1999, p. 7. "'Internacional' [com o prefixo 'inter' e o radical 'nação'] [...]”'

65 '[...] conveniente falar de 'transnacionalização', no sentido de que certos fluxos passam de uma nação para a outra sem que esse intercâmbio tenha a ver - ou que dependa exatamente, do direito nacional ou do direito internacional”. Ibid., p. 11.

66 ARNAUD, André-Jean. O direito entre a modernidade e a globalização: lições de filosofia do direito e do Estado. Tradução de Patrice Charles Wuillaume. Rio de Janeiro: Renovar, 1999, p. 15.

67 ROCHA, Leonel Severo. Palestra IEDC - Instituto de Estudos de Direito e Cidadania. Anais eletrônicos ... Disponível em: <http://www.iedc.org.br/artigo/dialogando/leonel. htm>. Acesso em: 11 jun. 2009. 
Emerge um novo fundamento axiológico, contra-hegemônico e relativamente harmônico, que direciona a um direito à vocação universal, não destinado "a substituir os direitos nacionais, mas a combinar-se com eles de maneira complementar e interativa" ${ }^{68}$. Em suma, o que se pretende é criar uma atmosfera propícia ao desenvolvimento de um cosmopolitismo jurídico, cuja noção experimentaria a tradução jurídica de preocupações éticas ${ }^{69}$.

Nesse caminho, os Direitos Humanos, como valor à vocação universal, vêm no intuito de superar a "falsa” dicotomia existente entre direitos nacionais e direito internacional, intensificada pela noção de Estado. A formação do Estado-Nação, engendrado pela modernidade e relacionado ao poder estatal ${ }^{70}$, representando, em síntese, a simples soma de indivíduos particulares, sem qualquer relação mais intensa entre si, à exceção da própria nacionalidade, foi e ainda é a causa imediata da propagação de um pluralismo normativo desenfreado e desordenado, gerador de assimetrias regulatórias, incidindo negativamente no aspecto social, mas reforçando e aprimorando o funcionamento do mercado (financeiro).

68 DELMAS-MARTY, Mireille. Les forces imaginantes du droit. Le relatif et l'universel. Paris: Éditions du Seuil, 2004. p. 43. "[...] les fragments d'un droit à vocation déjà universelle ne sont-ils pas destines à se substituer aux droits nationaux, mais à se combiner avec eux, de façon complémentaire et interactive".

69 Ibid., p. 115. "Rejoignant l'idée que le commerce internacional favorise une société ouverte e crée une atmosphére propice au développement d'um cosmopolitisme juridique, cette notion exprimerait la traducion juridique de préoccupations éthiques”.

70 O Estado Moderno ("Estado unitário dotado de um poder próprio independente de quaisquer outros poderes”) compõe-se de duas versões. A primeira, absolutista, nascida "das necessidades do capitalismo ascendente, na (ultra)passagem do período medieval”, com início no século XV. A segunda, na virada do século XVIII, inspirado pelo modelo liberal burguês, com avanço do absenteísmo da atividade estatal, cujas funções "circunscrevem-se à manutenção da ordem e segurança, zelando que as disputas porventura surgidas sejam resolvidas pelo juízo imparcial sem recurso a força privada, além de proteger as liberdades civis e a liberdade pessoal e assegurar a liberdade econômica dos indivíduos exercitada no âmbito do mercado capitalista”. STRECK, Lenio Luiz; MORAIS, José Luis Bolzan de. Ciência política e teoria do estado. 5. ed. rev. atual. Porto Alegre: Livraria do Advogado, 2006, p. 28, 39 e 61. Independentemente das possibilidades de versão do Estado Moderno, o que aqui se pretende ao tratar de Estado-Nação é indicar a forma de organização política centralizada composta pelos elementos característicos (povo, território e governo), com o "monopólio do sistema monetário, o monopólio do sistema fiscal, o monopólio da realização da justiça", e, sobretudo, o monopólio da produção normativa institucionalizada. Ibid., p. 44. 
Por outro lado, "o triunfo da ideia de direitos humanos na esfera doméstica dos Estados se insere em um longo processo de amadurecimento de concepções de natureza ética"71, muito embora se reconheça que a lógica global disseminada seja a mercadológica. A prevalência dos direitos econômicos em era de hegemonia globalizante, acarretando diretamente a total irregularidade dos parâmetros sociais mínimos nas diversas nações, norteia os ideais capitalistas de acumulação e propaga o individualismo por meio da evidente precarização das relações sociais em nome do primado do capital.

A formação de uma pauta de interesses harmônicos, com base em uma semântica universal, para a fundação de uma comunidade mundial de valores sem exterior, e a superação da pretensão regulatória normativa relativista estatal, se reflete nos direitos sociais. A ultrapassada noção de que os direitos sociais só existem quando as leis e as políticas sociais os garantirem equivale praticamente a um grau zero de proteção, reduzindo-os, irremediavelmente, a uma garantia platônica ${ }^{72}$.

71 LAFER, Celso. Comércio, desarmamento e direitos humanos: reflexões sobre uma experiência diplomática. São Paulo: Paz e Terra, 1999, p. 146.

72 CANOTILHO, J. J. Gomes. Direito Constitucional e Teoria da Constituição. 2. ed. Coimbra: Almedina, 1998, p. 439. "Cabe ressaltar que tanto os direitos sociais, como os direitos civis e políticos demandam do Estado prestações positivas e negativas, sendo equivocada e simplista a visão de que os direitos sociais só demandariam prestações positivas, enquanto que os direitos civis e políticos demandariam prestações negativas, ou a mera abstenção estatal. [...] os direitos civis e políticos não se restringem a demandar mera omissão estatal, já que a sua implementação requer políticas públicas direcionadas, que contemplam também um custo”. PIOVESAN, Flávia. Globalização econômica, integração regional e direitos humanos. In: PIOVESAN, Flávia (Org.). Direitos humanos, globalização econômica e integração regional: desafios do direito constitucional internacional. São Paulo: Max Limonad, 2002, p. 71.

72. A propósito dos constitucionalistas, José Afonso da Silva afirma serem os direitos sociais uma dimensão dos direitos fundamentais do homem "que possibilitam melhores condições de vida aos mais fracos, direitos que tendem a realizar a igualização de situações sociais desiguais. São, portanto, direitos que se ligam ao direito de igualdade. Valem como pressupostos do gozo dos direitos individuais na medida em que criam condições materiais mais propícias ao auferimento da igualdade real, o que, por sua vez, proporciona condição mais compatível com o exercício efetivo da liberdade”. SILVA, José Afonso da. Curso de direito constitucional. 15. ed., rev. e atual. São Paulo: Malheiros, 1998, p. 289-290. No ordenamento jurídico pátrio, o 
Daí que a viabilidade de conciliação entre os possíveis valores à vocação universal e a expansão mundial de parâmetros sociais em um modelo socioeconômico de exploração exige direitos mínimos a serem observados por todas as Nações, sobrepondo-se as diferenças culturais, com base em uma consciência espontânea de solidariedade humanista. Uma ação comunitária para a efetivação de efeitos sociais positivos decorre da vontade livre dos integrantes de manterem-se unidos em função de um interesse comum, maior a todos eles.

Por isso, as pautas apropriadas da convivência coletiva requerem um consenso axiológico transcultural que permita a instauração da universalização no campo dos direitos sociais. Um padrão mínimo ético de direitos mundialmente respeitados, cujo fundamento, tradução e diálogo repousam não simplesmente na função intermediadora das normas, mas em valores-guias que motivam e validam as condutas humanas.

A inserção do rol dos direitos sociais sob a tutela internacional de- corre da própria verificação evolutiva dos Direitos Humanos. A assunção dos atuais Direitos Humanos como legítimos direitos da humanidade instaurou-se por meio de um progresso histórico, o que importa concluir que "sempre haverá novos direitos sendo reclamados enquanto tais" ${ }^{73}$ " "O elenco de direitos do homem se modificou e continua a se modificar, com a mudança das condições históricas"74, por isso "não é difícil prever que, no futuro, poderão emergir novas pretensões que no momento nem sequer podemos imaginar" 75 .

A exigência de prestações estatais positivas, ou seja, da atuação do Estado no sentido de garantir condições sociais mínimas ao exercício de uma vida digna, já não é mais o bastante num mundo "sem fronteiras". As desigualdades sociais atuais aviltam a condição humana e criam uma massa de excluídos, completamente segregada das vantagens econômicas alcançadas e dos direitos indispensáveis.

A perspectiva econômica contemporânea descarta, manipula, oprime, aniquila aos que a ela se submetem,

elenco dos direitos sociais encontra previsão no rol do art. $6^{\circ}$ da Constituição Federal, in verbis: "São direitos sociais a educação, a saúde, o trabalho, a moradia, o lazer, a segurança, a previdência social, a proteção à maternidade e à infância, a assistência aos desempregados, na forma desta Constituição".

73 LIMA JÚNIOR, Jayme Benvenuto. Os direitos humanos econômicos, sociais e culturais. Rio de Janeiro: Renovar, 2001, p. 70.

74 BOBBIO, Norberto. A era dos direitos. Tradução de Carlos Nelson Coutinho. Rio de Janeiro: Campus, 1992, p. 18.

75 Ibid., 18-19. 
de modo que a presente tendência hegemônica abandona as conquistas sociais e volta-se exclusivamente à reprodução de riqueza. O efeito imediato é a desumanização ${ }^{76}$, fruto da ética dos interesses materiais, própria do sistema capitalista, restando por empregar uma lógica autodestrutiva: o sistema ameaça a sobrevivência humana, sem a qual esse mesmo sistema não pode existir, no que resulta que o capitalismo ameaça o capitalismo mesmo $^{77}$.

A noção de construção dos direitos sociais como valores universalizáveis resulta da constatação de que os Direitos Humanos podem representar limites pragmáticos a Lex Mercatoria e, em consequência, impor transnacionalmente condições sociais míni- mas de equidade e respeito a todas as pessoas. Tratar-se-ão de um "adquirido axiológico"78 que frustre, ou melhor, que "traduza" à escala mundial o "conflito misto que opõe mais largamente os direitos do homem ao mercado e o liberalismo econômico à ética da solidariedade e da partilha induzida pelos direitos sociais" ${ }^{79}$.

Nesse contexto, na condição de valor, os direitos sociais são apoiados no consenso histórico, sendo tanto mais fundados quanto mais aceitos ${ }^{80}$. Por isso, fazer crer na "universalidade de valores, no único sentido de que tal crença é historicamente legítima, ou seja, no sentido em que universal significa não algo dado objetivamente, mas algo subjetivamente acolhido pelo universo dos homens" ${ }^{\text {, }}$, impõe a

76 DELMAS-MARTY, Mireille. Aula do Collège de France de 25 de março de 2008. Áudio disponível em: <http://www.college-de-france.fr/default/EN/all/int_dro/cours_ du_18_mars_diffuse_le_2.jsp> Acesso em: 1 jul. 2009. A autora propõe o binômio humano/desumano, lembrando que o desumano tem a capacidade de redução do humano na alta potência, revelando-se em uma face perversa do humano.

77 HINKELAMMERT, Franz J. El sujeto y la ley: el retorno del sujeto reprimido. Heredia, C.R.: EUNA, 2003, p. 492.

78 LAFER, Celso. Comércio, desarmamento e direitos humanos: reflexões sobre uma experiência diplomática. São Paulo: Paz e Terra, 1999, p. 181.

79 DELMAS-MARTY, Mireille. Les forces imaginantes du droit. Le relatif et l'universel. Paris: Éditions du Seuil, 2004, p. 145. "Il est vrai qu'à l'echelle mondiale le conflit au sein dês droits de l'homme est considérablement aggravé par le conflit «miste» qui oppose plus largement les droits de l'homme au marché et le liberalisme économique à l'éthique de la solidarité et du partage induite par les droits sociaux".

80 BOBBIO, Norberto. A era dos direitos. Tradução de Carlos Nelson Coutinho. Rio de Janeiro: Campus, 1992, p. 27.

81 Ibid., p. 28. 
formação de uma verdadeira comunidade mundial que instaure o reconhecimento intrínseco e voluntário a todas as pessoas do direito a parâmetros sociais dignos.

Contudo, a positivação de direitos sociais não importa na sua efetividade. Não é função do direito "fazer sentir" os legítimos valores. "Os valores são um bem cultural. Têm um suporte, uma base na realidade, mas têm igualmente um significado que aponta para uma direção de 'dever ser'”82. Dada construção axiológica coletiva e universal contribui e influencia a formação do direito, mas não será o direito que tornará a observância desses valores efetiva.

O Direito simplesmente advém de toda a tradição axiológica de uma determinada sociedade, razão pela qual todo e qualquer texto normativo deve encontrar sua validade no contexto cultural. Disso decorre a necessidade de um fundamento axiológico "a priori" para o Direito que pressuponha um interesse comum ${ }^{83}$.

Daí que a eventual positivação de valores universais ou universalizáveis exercerá a função precípua de declarar o norte semântico e, talvez, prever alguma sanção por sua violação, não importando em sua efetividade, diga-se, se são ou não de fato observados pela coletividade. "A reivindicação de legalidade é apenas isso - uma reivindicação -, justificada pela importância ética de reconhecer que certos direitos constituem pretensões próprias de todos os seres humanos" ${ }^{84}$. Logo, os Direitos Humanos não devem ser identificados como direitos legais legislados $^{85}$, conclusão que se estende aos direitos sociais. Indo um pouco mais além: acaso assim fossem confundidos, resvalaríamos num completo "fosso do relativismo", em que

82 LAFER, Celso. Comércio, desarmamento e direitos humanos: reflexões sobre uma experiência diplomática. São Paulo: Paz e Terra, 1999, p. 180.

83 Nas lições de Robert Alexy, os direitos humanos são direitos morais, razão pela qual sua validade independe da positivação efetuada pela norma jurídica. Basta, para verificar a validade moral da norma, que, no plano moral, ela seja suscetível de ser justificada racionalmente perante todos aqueles que a aceitam. ALEXY, Robert. Direitos fundamentais no estado constitucional democrático. Revista de direito administrativo, v. 217, p. 58 e ss., jul./set. 1999. Nesse artigo, Alexy destaca cinco marcas de que são dotados os direitos humanos: são universais, morais, fundamentais, preferenciais e abstratos.

84 SEN, Armatya Kumar. Desenvolvimento como liberdade. São Paulo: Companhia das letras, 2000, p. 263 e 264.

85 SEN, loc. cit. 
cada "corpo normativo estatal” determina as disposições legais vigentes em seu espaço territorial, repercutindo em total assimetria global desses direitos.

Assim sendo, o compromisso com a concretização dos Direitos Humanos "caracteriza tarefa de todos, em comprometimento comum com a dignidade de todos"86. Importa estabelecer na comunidade internacional relações de respeito mútuo (entre países e entre os cidadãos) para o desenvolvimento comum $^{87}$, especialmente no terreno social, por meio de regras éticas, de conduta ou de deontologia ${ }^{88}$, pautadas no "mínimo ético irredutível”89.

Num mundo em que, pelo menos, "um terço da população mundial vive em extrema pobreza. Um milhão e trezentas mil pessoas ganham menos de U\$ 1,00 por dia; mais de $150 \mathrm{mi}-$ lhões de crianças estão mal nutridas e outras 100 milhões se encontram fora das escolas" ${ }^{90}$, preço de um modelo socioeconômico que premia a reprodução da riqueza nas mãos de poucos e incita a reprodução das disparidades

86 MORAIS, José Luiz Bolzan de. Direitos humanos globais (universais) de todos, em todos os lugares! In: PIOVESAN, Flávia (coord.). Direitos humanos, globalização econômica e integração regional: desafios do direito constitucional internacional. São Paulo: Max Limonad, 2002, p. 523.

87 LIMA JÚNIOR, Jayme Benvenuto. Os direitos humanos econômicos, sociais e culturais. Rio de Janeiro: Renovar, 2001, p. 68.

88 DELMAS-MARTY, Mireille. Três desafios para um direito mundial. Tradução Fauzi Hassan Choukr. Rio de Janeiro: Lumen Juris, 2003, p. 67.

89 PIOVESAN, Flávia. Direitos humanos e o direito constitucional internacional. 8. ed. rev., ampl. e atual. São Paulo: Saraiva, 2007, p. 150-151.

90 VIEIRA, Oscar Vilhena. Direitos humanos 50 anos depois. Palestra IEDC - Instituto de Estudos de Direito e Cidadania. Disponível em: <http://www.iedc.org.br/artigo/ dialogando/piovesan.htm>. Acesso em: 4 ago. 2009. Mireille Delmas-Marty relata, já no ano de 2003, que "no conjunto mundial, estima-se que a pobreza toca em torno de dois bilhões de pessoas, chegando a 5 bilhões em trinta anos. Isto traduz a urgência de uma ação internacional, tanto em escala regional como mundial”. Diante desse "quadro", argumenta a autora que "a resposta não pode ser puramente econômica, nem mesmo social, donde a dificuldade de uma legislação sobre os pobres. Não se pode mais - e não se deve mais - criar um estatuto do pobre como existe um estatuto do desempregado e, como reclamam alguns, o estatuto do imigrante. Além do que, os pobres 'não são', como diz Rilke em seu Le livre de la pouvreté et de la mort, 'eles não são senão privados dos bens essenciais e deixados à sorte, sem força e sem vontade’. Sejamos claros: não se trata de assistência, mas de integração à sociedade, com um estatuto de cidadania. Não se trata de sobreviver, mas de viver plenamente, com os outros homens, e reconhecido como seu semelhante”. DELMAS-MARTY, Mireille. op. cit. p. 56-57. 
sociais, a integração de valores para convivência coletiva ${ }^{91}$ universaliza a emancipação dos Direitos Humanos da tutela estatal, tornando-os oponíveis aos Estados ${ }^{92}$.

O respeito a condições sociais que contribua à humanização harmônica do modelo de desenvolvimento econômico impõe-se como reprimenda aos efeitos negativos dos parâmetros capitalistas atuais, sob pena de, no lugar de uma aldeia global, assistirmos à formação do saqueio global ${ }^{93}$. "Mas não bastará acumular textos e construir passarelas em papel. Ainda será necessário garantir a efetividade dessas nor- mas, condição de validade empírica

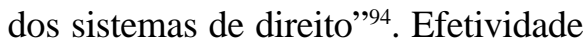
normativa, aliás, como conteúdo-chave dos particularismos estatais, admitindo a repercussão social da norma de acordo com as perspectivas e características inerentes a cada sistema.

Esbarra-se, aqui, na problemática do multiculturalismo. Se o reconhecimento de múltiplos sistemas jurídicos válidos é um dado, a admissão da diversidade cultural é seu fundamento. "As tradições, os dados históricos, culturais e religiosos de cada Nação, e os valores de cada povo, não podem ser ignorados”,95, do que decorre a pa-

91 LAFER, Celso. Comércio, desarmamento e direitos humanos: reflexões sobre uma experiência diplomática. São Paulo: Paz e Terra, 1999, p. 146, 194.

92 DELMAS-MARTY. Mireille. La mondialisation du droit: vers une communauté de valeurs? Disponível em: <http://www.millenaire3.com/uploads/tx_ressm3/TU_ Delmas_Marty240108.pdf >. Acesso em: 4 ago. 2009. "Du point de vue politique, les Droits de l'Homme se sont progressivement emancipes de leur occidentalisme, au point d'être invoques à l'appui de la décolonisation. Les Droits de l'Homme se sont aussi émancipés de leur tutelle étatique, jusqu'á devenir opposables aux Etats".

93 GIDDENS, Anthony. Un mundo desbocado: los efectos de la globalización em nuestras vidas. Tradução de Pedro Cifuentes. Buenos Aires: Taurus, 2003, p. 28. Digase, a título de destaque, o evidente saqueio global da tutela social, o que, a termo, resta por motivar e justificar com requinte a descartabilidade do ser humano.

94 DELMAS-MARTY, Mireille. Les forces imaginantes du droit. Le relatif et l'universel. Paris: Éditions du Seuil, 2004, p. 168. "Mais il ne suffira pas d'accumuler des textes et de construire passarelas em papel. Encore faudra-t-il garantir l'effectivité de ces nomes, condition de la validité empirique des systèmes de droit”.

95 TRINDADE, Antônio Augusto Cançado. Tratado de direito internacional dos direito humanos, vol. 1. Porto Alegre: Sérgio Fabris Editor, 1997, p. 222. Reprodução dos argumentos e percepções da Delegação da Líbia na Conferência Mundial de Direitos Humanos de 1993. 
tente assimetria dos Direitos Humanos Sociais nas diferentes culturas.

Por tudo isso, "o momento parece então chegado, não de renunciar ao pluralismo cultural, mas de conceber como a variabilidade que aqui resulta possa contribuir a 'geradora de diversidade' que servirá a imaginar a norma comum aceitável por todos ${ }^{96 ”}$. A diversidade cultural servirá de ponto de partida para o alcance do compartilhamento de um norte semântico proposto por uma linguagem moral universal. Respeitar as diferenças é também propor um denominador comum, do que decorre a implementação da verdadeira igualdade.
Nesse caminho está a importância da "realização de diálogos interculturais, que identifiquem constelações axiológicas comuns nas diferentes culturas"97, como a única "forma apta a propiciar a consolidação dos elos sociais que definem, em última instância, a eficácia internacional dos direitos humanos" ${ }^{98}$. Partir das diferenças culturais para superação das assimetrias é o modo mais tranquilo de construção de uma ação comunitária para a efetivação de efeitos sociais globais positivos.

Definitivamente "nenhuma cultura tem a 'boa resposta', cada uma deve se aprofundar para procurar uma resposta comum compatível com suas próprias referências”99. Nesse aspec-

96 DELMAS-MARTY, Mireille. Les forces imaginantes du droit. Le relatif et l'universel. Paris: Éditions du Seuil, 2004, p. 24. “Dans l'immédiat, le risque est cependant la tentation hégémonique du pays le plus puissant et les reactions nationalists des autres. Le plus probable est donc de voir se renforcer une discontinuité à fronts renversés dejà observable: à mesura que l'universalisme devient normatif, on voit en effect se développer un nouveau relativisme, abstrait et théorique, qui oppose à l'internationalisation du droit des arguments quasi théologiques mais il semble céder le pas devant la globalization. Le moment semble donc venu, non de renoncier au pluralisme culturel, mais de concevoir comment la variabilité qui en résulte pourrait contribuer ao 'générateur de diversité' qui servira à imaginer la norme commune acceptable par tous”.

97 AMARAL JÚNIOR, Alberto do. A institucionalização dos direitos humanos: conquistas e desafios. In: Direitos humanos, globalização econômica e integração regional: desafios do direito constitucional internacional. São Paulo: Max Limonad, 2002, p. 650.

98 AMARAL JÚNIOR, loc. cit.

99 DELMAS-MARTY. Mireille. La mondialisation du droit: vers une communauté de valeurs? Disponível em: <http://www.millenaire3.com/uploads/tx_ressm3/TU_ Delmas_Marty240108.pdf>. Acesso em: 4 ago. 2009. “Aucune culture n'a de 'bonne réponse’, chacune doit s’approfondir pour chercher une réponse commune compatible avec ses propres repéres”. 
to, o enfraquecimento da normatividade estatal, em favor do mercado, com a gradual e acelerada mudança da função do Estado, eleva os limites fixados pelos marcos normativos internacionais para formação da via do diálogo e do aprofundamento, o que traz à mente a metáfora da esfera ${ }^{100}$. Os Direitos Humanos, certamente, são mecanismos aptos a estabelecer pontos de contato culturais comuns para a fundação de uma comunidade mundial que "não é somente uma comunidade interestatal ou internacional, mas uma comunidade inter-humana"101, mundial, supranacional, fundada, senão politicamente, ao menos na ética e no direito ${ }^{102}$.

\section{CONSIDERAÇÃOS FINAIS}

O reconhecimento da diversidade cultural e, por consequência, da possível e provável assimetria de valores tornam a proposta de conferir o status de "vocação universal" aos Direitos Humanos árdua, mas também suscetível aos riscos da uniformização não pluralista ${ }^{103}$. A questão está em separar a noção de Direitos Humanos enquanto universais de sua identificação enquanto construção do modelo ocidental, induzindo à destruição da diversidade ${ }^{104}$. O desafio está em trabalhar com essa multiplicidade, valendo-se dela para elaboração de um discurso ético, por meio de "um dialo-

100 A metáfora da esfera é proposta por Paul Ricouer: "se eu tento correr na superfície da esfera, eu não encontrarei jamais o universal, eu farei um sincretismo. Mas se eu me aprofundo na minha tradição, eu atalho a distância em relação aos outros na dimensão da profundidade. Na superfície a distância é imensa, mas se eu me aprofundo, eu me aproximo do outro, à condição de que ele percorra o mesmo caminho”. DELMASMARTY, Mireille. Aula do Collège de France de 18 de março de 2008. Áudio disponível em: <http://www.college-de-france.fr/default/EN/all/int_dro/cours_du_25_ mars_diffuse_le_1.jsp>. Acesso em: 30 jun. 2009.

101 DELMAS-MARTY, Mireille. Aula do Collège de France de 13 de maio de 2008. Áudio disponível em: <http://www.college-de-france.fr/default/EN/all/int_dro/>. Acesso em: 30 set. 2009.

102 DELMAS-MARTY, Mireille. Aula do Collège de France de 05 de março de 2007. Áudio disponível em: <http://www.college-de-france.fr/default/EN/all/int_dro/ cours_5.jsp>. Acesso em: 30 jun. 2009.

103 DELMAS-MARTY, Mireille. Três desafios para um direito mundial. Tradução Fauzi Hassan Choukr. Rio de Janeiro: Lumen Juris, 2003, p. 9. "Do lado da economia, e mais precisamente do direito econômico, trata-se, com efeito, de globalização, caso seja entendida como a difusão espacial em escala global; mas se trata com mais frequência de uma difusão unilateral e, portanto, uniformizadora e não pluralista. Daí o risco evidente de uma mundialização hegemônica que não exprima nada além do que a lei do mais forte”. 
go atualizado e de estruturas que permitam mudanças contínuas, de modo que uma norma seja vista sob todas as perspectivas" 105 .

Contudo, as ameaças próprias da desordem normativa no campo dos Direitos Humanos, originando assimetrias de um pluralismo normativo de sobreposição (cada Estado legisla no e para seu domínio, provocando um "acavalamento" entre diferentes marcos normativos - nacionais, re- gionais e internacionais), acarretam práticas sociais globais desiguais, cuja variabilidade importa um total relativismo ${ }^{106}$. Próprio da diversidade cultural, a inexistência de parâmetros sociais mínimos acirra e contribui para a disparidade econômica entre as nações centrais e periféricas, de forma que, para construção de um sentido universal fundado em valores comuns, dificulta o processo de formação de uma comunidade mundial

104 PIOVESAN, Flávia. Direitos humanos e o direito constitucional internacional. 8. ed. rev., ampl. e atual. São Paulo: Saraiva, 2007, p. 151.

105 VIEIRA, Oscar Vilhena; DUPREE, A. Scott. Reflexões acerca da sociedade civil e dos direitos humanos. SUR - Revista Internacional de Direitos Humanos, ano 1, n. 1, $1^{\circ}$ semestre, 2004, p. 57.

106 Aliás, no plano internacional, os Direitos Humanos acabam por não alcançar um bom grau de obrigatoriedade entre os Estados. Por isso a necessidade de encará-los como obrigações erga omnes, mais do que meras recomendações aos Estados. Tratamse, como lembra Antônio Augusto Cançado Trindade, de um jus cogens, constituído por um corpus iuris marcado por uma lógica própria de um direito de proteção. Logo, não é dado cindi-los conforme os interesses particulares das nações. “O Direito Internacional dos Direitos Humanos se insurge contra a seletividade discricionária, seja no tocante aos destinatários da norma, seja em relação às condições de aplicação das mesmas. Quanto aos primeiros, sustenta que os direitos humanos se impõem de igual modo, consoante os mesmos critérios, a todos os países. Quanto às segundas, não admite que se 'escolham' determinados direitos a promover e proteger à exclusão dos demais, adiando a realização desses a um futuro indefinido, geralmente sob o pretexto de alegada falta de recursos materiais. Não admite, em suma, que se sacrifiquem gerações, com a promessa vaga e enganosa de só assim poder começar a construir 'futuro melhor'. Tais visões fragmentadas, no espaço e no tempo, alentadas pelos detentores do poder arbitrário, não se coadunam com o propósito último do Direito Internacional dos Direitos Humanos de assegurar a proteção integral do ser humano em todas as áreas da atividade humana e em todas e quaisquer circunstâncias. Não há justificativa para a seletividade no presente domínio de proteção. Erigido para defender a pessoa humana contra toda as formas de dominação e arbitrariedade, o presente corpus iuris de proteção forma um todos harmônico e indivisível”. TRINDADE, Antônio Augusto Cançado. Tratado de direito internacional dos direito humanos. V. 1. Porto Alegre: Sérgio Fabris Editor, 1997, p. 20 e 25-26. 
que "concilie" interesses culturais divergentes e antagônicos.

Não se pode negar, por outro lado, que, como reflexo das consequências negativas da Segunda Guerra, “as políticas de direitos humanos estiveram em geral a serviço dos interesses econômicos e geopolíticos dos Estados capitalistas hegemônicos” ${ }^{107}$, daí porque sua ocidentalização. Aquilo que se compreende por Direitos Humanos universais hoje está diretamente relacionado a uma noção ocidental de mundo, muito arraigada à visão socioeconômica da propriedade privada dos meios de produção, diga-se, capitalista, e, acima de tudo, extremamente individualista.

Contudo, a cultura pesa na institucionalização dos valores e o diálogo intercultural decorre diretamente do reconhecimento das incompletudes culturais. A questão nodal é partir das diferenças para a construção de um horizonte de sentido comum. A resposta sobre a natureza dos Direitos Humanos Sociais não resulta da experiência cultural particular de um povo, mas dada solução advém de uma reflexão filosófica que supere os particularismos.

As vicissitudes de cada cultura é exatamente o que autoriza a percep- ção das fragilidades de cada uma delas e, assim, a imprescindível complementaridade com as demais. Deve-se perceber que as incompletudes culturais são o espaço de racionalização de um denominador comum, em direção a um ponto de equilíbrio. Por isso, a instauração de um norte de sentido universal para uma pauta de interesses harmônicos, em uma comunidade sem exterior, que inclua a toda e qualquer pessoa e se assente na simples condição de "ser humano".

O grande desafio é indicar padrões mínimos de conduta a serem globalmente respeitados. Fixar limites à exploração humana, por meio de mecanismos mundialmente aceitos, exige um consenso axiológico transcultural que se guia por um universalismo de confluência, cuja expressão máxima são os Direitos Humanos, particularmente os Direitos Humanos Sociais.

O que se busca é uma construção axiológica que viabilize a instauração de valores universalizáveis fundantes de uma comunidade inter-humana, sem exterior. Tais valores serão hábeis a determinar o sentido das normas aplicáveis e o expresso reconhecimento de vetores de conduta pelos instrumentos internacionais, permitindo que se pense em alternativas conciliadoras entre a

107 SANTOS, Boaventura de Sousa. Por uma concepção multicultural de direitos humanos. In: SANTOS, Boaventura de Sousa (Org.). Reconhecer para libertar: os caminhos do cosmopolitismo multicultural. Rio de Janeiro: Civilização Brasileira, 2003, p. 440. 
globalização econômica e a universalização dos direitos sociais. Trata-se de um projeto cosmopolítico que discipline a "inserção de valores morais, que se encontram num patamar anterior, e superior, ao próprio sistema positivo"108. "Globalizar" e "universalizar", fenômenos que, se bem trabalhados, são fundamentais para a instauração de uma "relação equilibrada e mutuamente fortalecedora entre a competência global e a legitimidade local”, precondição de uma política contra-hegemônica de Direitos Humanos, transformados à luz do que é chamado de multiculturalismo emancipatório ${ }^{109}$.

Por isso, orientar, direcionar, guiar as ações humanas, trabalhando com a diversidade cultural para elaboração de um discurso ético comum, encontra nos valores universais a possibilidade de uma mesma norma ser vista sob todas as perspectivas. Garantir a todos os seres humanos os direitos necessários ao exercício pleno de sua humanidade é a missão dos Direitos Humanos, o que permite atribuir-lhes a condição de um valor transnacional que encontra nas diferentes culturas a sua limitação semântica.

108 BARRETO, Vicente de Paulo. Direito cosmopolítico e direitos humanos. Estudos Jurídicos, São Leopoldo, v. 40, n. 2, p. 100-103, julho-dezembro 2007, p. 102.

109 SANTOS, Boaventura de Sousa. Por uma concepção multicultural de direitos humanos. In: SANTOS, Boaventura de Sousa (Org.). Reconhecer para libertar: os caminhos do cosmopolitismo multicultural. Rio de Janeiro: Civilização Brasileira, 2003, p. 438. "É sabido que os direitos humanos não são universais na sua aplicação. Atualmente são consensualmente identificados quatro regimes internacionais de aplicação de direitos humanos: o europeu, o interamericano, o africano e o asiático. Mas serão os direitos humanos universais como artefato cultural, um tipo de invariante cultural ou transcultural, parte de uma cultura global? A minha resposta é não. Ainda que todas as culturas tendam a definir os seus valores mais importantes como os mais abrangentes, apenas a cultura ocidental tende a formulá-los como universais. Por isso mesmo, a questão da universalidade dos direitos humanos trai a universalidade do que questiona ao questioná-lo. Em outras palavras, a questão da universalidade é uma questão particular, uma questão específica da cultura ocidental. [...] paralelamente aos discursos e práticas que fazem dos direitos humanos um localismo globalizado, têm sido desenvolvidos discursos e práticas contra-hegemônicos que, além de verem nos direitos humanos uma arma de luta contra a opressão independente de condições geoestratégicas, apresentam propostas de concepções não ocidentais de direitos humanos e organizam diálogos interculturais sobre os direitos humanos e outros princípios de dignidade humana. À luz destes desenvolvimentos, creio que a tarefa central da política emancipatória do nosso tempo consiste em transformar a conceitualização e a prática dos direitos humanos de um localismo globalizado, em um projeto cosmopolita”, p. 438-441. 
É indispensável a introdução de uma nova gramática contemporânea à realidade capitalista. Propor a instauração de uma linguagem comum, fundada em valores universais, ou universalizáveis, subjetivamente acolhida pelo uni- verso de homens, importa reconhecer que a hierarquização de valores agrega-se à possível universalização dos direitos sociais, os quais, enquanto Direitos Humanos, são também o retrato da proteção do direito à dignidade humana.

\section{REFERÊNCIAS}

ALEXY, Robert. Direitos fundamentais no estado constitucional democrático. Revista de direito administrativo, v. 217, p. 58 e ss., jul./set. 1999.

ALVES, Giovanni; WOLFF, Simone. Capitalismo global e o advento de empresas-rede: contradições do capital na quarta idade da máquina. Caderno CRH, Salvador, v. 20, n. 51, p. 515-528, set./dez. 2007.

AMARAL JÚNIOR, Alberto do. A institucionalização dos direitos humanos: conquistas e desafios. In: Direitos humanos, globalização econômica e integração regional: desafios do direito constitucional internacional. São Paulo: Max Limonad, 2002.

ARNAUD, André-Jean. $O$ direito entre a modernidade e a globalização: lições de filosofia do direito e do Estado. Tradução de Patrice Charles Wuillaume. Rio de Janeiro: Renovar, 1999.

BARRETO, Vicente de Paulo. Direito cosmopolítico e direitos humanos. Estudos Jurídicos, São
Leopoldo, v. 40, n. 2, p. 100-103, julho-dezembro 2007.

BAUMAN, Zygmunt. Modernidade líquida. Tradução Plínio Dentzein. Rio de Janeiro: Jorge Zahar, 2001.

BOBBIO, Norberto. A era dos direitos. Tradução de Carlos Nelson Coutinho. Rio de Janeiro: Campus, 1992.

CANOTILHO, J. J. Gomes. Direito Constitucional e Teoria da Constituição. 2. ed. Coimbra: Almedina, 1998.

COMPARATO, Fábio Konder. A Afirmação Histórica dos Direitos Humanos. 3. ed. São Paulo: Saraiva, 2003.

COSTA, Sérgio. Democracia cosmopolita: déficits conceituais e equívocos políticos. Revista brasileira de Ciências Sociais, São Paulo, v. 18, n. 53, 2003. Disponível em: <http://www. scielo.br/scielo.php?script $=$ sci_ a r t t e x t \& p i d = S 0102 $-69092003000300002 \& \operatorname{lng}=e n \& n$ rm=iso $>$. Acesso em: 30 jun. 2009. 
DELMAS-MARTY, Mireille. Três desafios para um dieito mundial. Tradução Fauzi Hassan Choukr. Rio de Janeiro: Lumen Juris, 2003.

- Ordem jurídica mundial e paz positiva. Entrevista a Le Monde Diplomatique. Disponível em: <http://diplo.uol.com. br/2003-07,a691>. Acesso em: 29 jun. 2009.

- Le rôle du droit dans l'émergence d'une communaute mondiale de valeurs. Aula ministrada, em 7 de setembro 2008, em Paris. Disponível em: <http:// www.asmp.fr/travaux/communications/2008/delmas.htm>. Acesso em: 31 mai. 2009.

Aula do Collège de France de 18 de março de 2008. Áudio disponível em: <http://www.college-de-france.fr/default/EN/all/ int_dro/cours_du_25_mars_diffuse_le_1.jsp>. Acesso em: 30 jun. 2009.

- Entrevista para Lettre du Collège de France, $\mathrm{n}^{\circ}$ 22, fév. 2008. Disponível em: <http:// www.college-de-france.fr/media/ int_dro/UPL17566_J22INTDELMAS.pdf $>$. Acesso em: 30 jun. 2009.

Aula do Collège de France de 25 de março de 2008. Áudio disponível em: <http://www.college-de-france.fr/default/EN/all/ int_dro/cours_du_18_mars_di- ffuse_le_2.jsp> Acesso em: 1 jul. 2009.

. Aula do Collège de France de 13 de maio de 2008. Áudio disponível em: <http://www.college-de-france.fr/default/EN/all/int_ dro/> . Acesso em: 30 set. 2009.

. Aula do Collège de France de 5 de março de 2007. Áudio disponível em: <http://www.college-de-france.fr/default/EN/all/ int_dro/cours_5.jsp>. Acesso em: 30 jun. 2009.

Les forces imaginantes du droit. Le relatif et l'universel. Paris: Éditions du Seuil, 2004. Por um direito comum. São Paulo: Martins Fontes, 2004. La mondialisation du droit: vers une communauté de valeurs? Disponível em: <http://www.millenaire3.com/uploads/tx_ressm3/ TU_Delmas_Marty240108.pdf >. Acesso em: 4 ago. 2009.

DUPAS, Gilberto. Impactos sociais e econômicos das novas tecnologias de informação. In: SIMPÓSIO INTERNACIONAL UNIVERSIDADE E SOCIEDADE, 1999, Anais eletrônicos. São Paulo: Faculdade de Economia, Administração e Contabilidade - USP, 1999. Disponível em: <http://www.ime.usp.br/ cesar/ simposio99/Dupas.htm>. Acesso em: 29 jun. 2009.

ENGELMANN, Wilson. A origem jusnaturalista dos direitos hu- 
manos: o horizonte histórico da declaração universal dos direitos humanos de 1948. Artigo apresentado no CONPEDI - Conselho Nacional de Pesquisa e Pós-Graduação em Direito, julho, 2009.

FARIA, José Eduardo. $O$ Direito na economia globalizada. São Paulo: Malheiros Editores, 1999. . Globalização e Justiça. In: CAMPUZANO, Afonso de Julios; OLIVEIRA JUNIOR, José Alcebíades de (Org.). O poder das metáforas: homenagem aos 35 anos de docência de Luis Alberto Warat. Porto Alegre: Livraria do Advogado, 1998.

GALUPPO, Marcelo Campos. A epistemologia jurídica entre o positivismo e o pós-positivismo. Revista do instituto de hermenêutica jurídica, Porto Alegre, v. 1, n. 3, 2005.

GIDDENS, Anthony. Un mundo desbocado: los efectos de la globalización em nuestras vidas. Tradução de Pedro Cifuentes. Buenos Aires: Taurus, 2003.

GONZÁLEZ, Rodrigo Stumpf. A retórica dos direitos humanos. In: SANTOS, André Leonardo Copetti; STRECK, Lenio Luiz; ROCHA, Leonel Severo. Constituição, sistemas sociais e hermenêutica: programa de pós-graduação em Direito da UNISINOS: mestrado e doutorado. Porto Alegre: Livraria do Advogado, 2007.
HINKELAMMERT, Franz J. El sujeto y la ley: el retorno del sujeto reprimido. Heredia, C.R.: EUNA, 2003.

HOBSBAWM, Eric. O novo século: entrevista a Antonio Polito. São Paulo: Companhia das Letras, 2000.

JUNGES, Roque. A concepção kantiana de dignidade humana. Estudos Jurídicos, v. 40, n. 2, p. 84-87, julho-dezembro 2007.

KANT, Immanuel. Fundamentação da metafísica dos costumes. Tradução de Lourival de Queiroz Henkel. São Paulo: Ediouro, 1967.

LAFER, Celso. Paz, direitos humanos e multiculturalismo. Jornal da Ciência, 20 dez. 2004. Disponível em: <http://www.jornaldaciencia. org.br/Detalhe.jsp?id=24172>. Acesso em: 30 jun. 2009.

. Comércio, desarmamento e direitos humanos: reflexões sobre uma experiência diplomática. São Paulo: Paz e Terra, 1999.

LIMA JÚNIOR, Jayme Benvenuto. Os direitos humanos econômicos, sociais e culturais. Rio de Janeiro: Renovar, 2001.

LUCAS, Douglas Cesar. Direitos humanos e interculturalidade: um diálogo entre igualdade e diferença. Tese (Doutorado em Direito) - Programa de Pós-Graduação em Direito, Unisinos, São Leopoldo, 2008. 
MAGNOLI, Demétrio. Globalização: estado nacional e espaço mundial. São Paulo: Moderna, 1997.

MORAIS, José Luiz Bolzan de. Direitos humanos globais (universais) de todos, em todos os lugares! In: PIOVESAN, Flávia (coord.). Direitos humanos, globalização econômica e integração regional: desafios do direito constitucional internacional. São Paulo: Max Limonad, 2002.

\section{ORGANIZAÇÃO DAS NAÇÕES} UNIDAS PARA A EDUCAÇÃO, A CIÊNCIA E A CULTURA - UNESCO. Declaração Universal sobre Bioética e Direitos Humanos de 19 de outubro de 2005. Disponível em: <http://unesdoc.unesco.org/ images/0014/001461/146180S. pdf>. Acesso em: 14 dez. 2009.

PIOVESAN, Flávia. Direitos humanos e o direito constitucional internacional. 8. ed. rev., ampl. e atual. São Paulo: Saraiva, 2007.

. Palestra IEDC - Instituto de

Estudos de Direito e Cidadania. Anais eletrônicos. Disponível em: $<$ http://www.iedc.org.br/artigo/ dialogando/piovesan.htm>. Acesso em: 11 jun. 2009.

- Globalização econômica, integração regional e direitos humanos. In: PIOVESAN, Flávia (org.). Direitos humanos, globalização econômica e integração regional: desafios do direito constitucional internacional. São Paulo: Max Limonad, 2002.

ROCHA, Leonel Severo. Palestra IEDC - Instituto de Estudos de Direito e Cidadania. Anais eletrônicos. Disponível em: <http://www.iedc.org. br/artigo/dialogando/leonel.htm>. Acesso em: 11 jun. 2009.

SANTOS, Milton. Por uma outra globalização: do pensamento único à consciência universal. 10 ed. Rio de Janeiro: Record, 2003.

SANTOS, Boaventura de Sousa. Por uma concepção multicultural de direitos humanos. In: SANTOS, Boaventura de Sousa (Org.). Reconhecer para libertar: os caminhos do cosmopolitismo multicultural. Rio de Janeiro: Civilização Brasileira, 2003.

SARLET, Ingo Wolfgang. Dignidade da Pessoa Humana e Direitos Fundamentais na Constituição de 1988. 2. ed. Porto Alegre: Livraria do Advogado, 2002.

SEN, Armatya Kumar. Desenvolvimento como liberdade. São Paulo: Companhia das letras, 2000.

SILVA, José Afonso da. Curso de direito constitucional. 15. ed., rev. e atual. São Paulo: Malheiros, 1998.

SINGER, Paul. Uma utopia militante: repensando o socialismo. Petrópolis: Vozes, 1998.

STRECK, Lenio Luiz; MORAIS, José Luis Bolzan de. Ciência politica e teoria do estado. 5. ed. rev. atual. Porto Alegre: Livraria do Advogado, 2006. 
TRINDADE, Antônio Augusto Cançado. Tratado de direito internacional dos direito humanos. V. 1. Porto Alegre: Sérgio Fabris Editor, 1997.

VENTURA, Deisy de Freitas Lima; KILCA, Marcelo. Constitucionalização da União Europeia em processo: para além do meramente jurídico. Revista dos Alunos do Programa de Pós-Graduação em Integração Latino-Americana UFSM, Santa Maria, v. 2, n. 2, 2006. VENTURA, Deisy de Freitas Lima. Critica al proyecto de Constitución Europea ("Constitución parcial”): La Convención como mo- desto laboratorio del constitucionalismo supranacional. Revista de Derecho Privado y Comunitario, Buenos Aires, 2003-3.

VIEIRA, Oscar Vilhena. Direitos humanos 50 anos depois. Palestra IEDC - Instituto de Estudos de Direito e Cidadania. Disponível em: <http://www.iedc.org.br/artigo/dialogando/piovesan.htm>. Acesso em: 4 ago. 2009.

VIEIRA, Oscar Vilhena; DUPREE, A. Scott. Reflexões acerca da sociedade civil e dos direitos humanos. SUR - Revista Internacional de Direitos Humanos, ano 1, n. 1, $1^{\circ}$ semestre, 2004. 